\title{
Plano Nacional de Obras, Empreendimentos e Serviços Municipais
}

\author{
(Drojeto $4.614 / 54$ )
}

Senador Jarbas Maranhão

A Revista do Serviço Público, atendendo a solicitaçōes de vários parlamentares, técnicos e estudiosos, divulga na presente edição, o Projeto $n^{\circ} 4.614 / 54$ que o Senador Jarbas Maranhão apresentou quando Deputado, na Câmara Federal. Trata-siz do famoso Plano Nacional de Obras, Empreendimentos e Serviços Municipais cujo andamento nas duas Casas do Congresso Nacional vai ser acelerado por iniciativa do Grupo Parlamentar Municipalista liderado pelos Deputados Osmar Cunha, Aniz Bedra, Nelson Omegna, Océlio de Medeiros, Souto Maior, Andrade Lima Filho, Ney Braga, Cunha Bueno, Cimenor Freitas - pata citat, apenas, os parlamentares que mais ativamente têm participado dos debates travados a respeito dos problemas fundamentais dos Municipios. Sob certos aspectos justifica-se a demora verificada no exame e discussão do Projeto 4.614/54, em virtude da sua natural complexidadiz e dos grandes interêsses em jôgo. $O$ atraso observado no andamento dessa revolucionária proposição legislativa é. em parte, decorrente do vulto das despesas que seriam efetuadas por fôtça de sua execução. As estimativas mais conservadoras calculam em dezoito bilhões de cruzeiros $(18.000 .000 .0000,00)$ e cêrca de cem milhões de dólares (US $\$ 100,0000,000,00)$ o custo das aplicações diretas de capital - investimentos especiais, empréstimos e financiamentos entre outras despesas - na execução das obtas, empreendimentos, serviços e projetos geradores de riqueza - consubstanciados no Sistema Geral da Operação Municipio de que o Plano Nacional proposto pelo Senador Jarbas Maranhão é, apenas, o prelúdio. A partir da data de sua apresentação, - Projeto 4.614/54 recebeu diversos substitutivos, dentre os quais se destacam, pela stua importância, os do Vice-Governador fluminense, então Deputado, Celso Peçanha, a "Lei Pró-Municipio" de TeIXeIRA DE FreItAs (encaminhada, sob 
os auspicios da A.B.M. pelo Deputado Antunes De OliveiRA) e as contribuições especializadas dos Lideres das Bancadas que se pronunciaram sôbre o problema. A situação da Operação Municipio, no Congresso Nacional é, sob muitos ângulos, semelhante à da Eletrobrás, à do Plano de Classificação dos Cargos e Funções dos Serviços Públicos, à rlegulamentação dos dispositivos constitucionais básicos, à Reforma Administrativa, e a inúmeras outras proposições legislativas de grande envergadura que, pelo vulto das suas proporçóes e volume de despesas, têm, naturalmente um andamento moroso e sofrem o impacto de emendas de tôda a ordem. Aproxima-se, porém, - momento em que o Poder Legislativo deverá se manifestar. em definitivo a resplzito do Plano Nacional de Obras, Empreendimentos e Serviços Municipais (Operação Municipio) motivo pelo qual a Revista do Serviço Público deliberon publicar os documentos originais que the deram inicio na Câmara dos Deputados. Manifestandorse sôbre o magno Projeto 4.614/54 no Prefácio que escreveu para o livro recentemente editado pelo Serviço de Documentação do D.A.S.P., de autoria do Senador JaRBAS MARANHÃo, intitulado "Municipalismo e Ruralismo" (Rio, 1960), o escritor Manoel Caetano BandeIRA DE Mello teve oportunidade de acentuat: "O senador Jarbas Maranhão tem sido no Parlamento destacado intérprete das necessidades e aspirações das Comunas, Prefeituras e Câmaras de todo o Brasil; e dos problemas das populações rurais. A preocupação absorvente do Senador pernambucano é no sintido de obter soluçóes arrojadas, práticas e definitivas para os referidos problemas dentre os quais avultam o subdesenvolvimento e o pauperismo das zonas rurais. A Operação Municipio - ora em andamento no Congresso Nacional - representa, inegàualmente, a contribuição máxima que um Legistador poderia apresentar em benefício de sua terra e de seu Povo. O advento da Operação Municipio - que está sendo anciosamente esperada e teivindicada pelas Prefeituras e Câmaras de Vereadores de todo o Brasil constitui, na verdade, o objetivo supremo do Movimento Municipalista brasileiro. Com o Projeto $n^{\circ} 4.614-54$ prestou o Senadot Jarbas MARAnHão o maior dos serviços ao desenvolvimento global e descentralizado das Unidades Elementares da Federação - cêtca de 2.800 Municipios -, traçando-lhes o roteiro da administração planificada emancipação econômica e do bem-estar social". A Revista do Serviço Público cumpre - seu dever de bem informar os seus milhares de leitores e assinantes, ao divulgar, com o destaque que merece, o Projeto de Lei 4.614/54 - iniciativa da maior significação para a Nação Brasileita.

Considerando que, a partir da apresentação na Câmara Federal do Projeto $n^{\circ} 4.614 / 54$ (Operação Municipio), de 
autoria do, hoje Senador JARBAS MARANHÃO, foi iniciada uma fase na história do Municipalismo brasileiro;

Considerando que, a partir da apresentação do referido Projeto, đzve inicio e se encontra em plena organização um movimento politico e técnico-cultural no sentido de proporcionar aos Municipios brasileiros condições objetivas e práticas para - set progresso, deixando de ser, assim, a autonomia municipal uma simples ficção;

Considerando que, desde a apresentação do Projeto da Operação Municipio, surgiram, nas Assembléias Legislativas de diversos Estados da Federação, projeções regionais que constituem adaptações inteligentes e práticas das idéias contidas no referido Projeto;

Considerando que, no âmbito municipal, está sendo processada, de fato, a implantação do Sistema Geral da Operação Municipio, através de projeções locais destinadas a acelerat - ritmo do desenvolvimento municipal, com planos diretores, investimentos geradores de riquaza, urbanismo avançado, aproveitamento de todos os valores locais;

Considerando que o Sistema Geral da chamada Operação Municipio significa, na prática, a aplicação concentrada de recursos financeiros de vulto, provenientes das três órbitas de Govêrno (Federal, Estadual e Municipal), e representa, também, a execução de projetos geradores de riqueza;

Considerando que é de plena e total exeqüibilidadia técnica e financeira, também politica e econômica. o Sistema Geral da Operação Municipio e suas projeções regionais e locais;

Considerando que a Operação Municipio dinamiza as fôrças latentes que existem nas Comunas brasilıiras e que precisam ser aplicadas no sentido de libertar, efetivamente, os Municipios do Brasil, possibilitando-lhes condições reais de desenvolvimento 1 e progresso, tornando os Municipios auto suficientes em alguns setores, fixando, naturalmente, o homem à sua gleba e fortalecendo a unidade nacional: - o IV Congresso Nacional dos Municipios resolve:

- Os Prefeitos le Vereadores do Brasil, bem como os técnicos e estudiosos do Municipalismo, ora reunidos neste Congresso, recomendam aos Podêres constituidos da República e aos lideres das agremiações politico-partidárias que sejam tomadas tôdas as providências no sentido de que o Sistema Geral da Operação Municipio e tôdas as suas projeções regionais e locais, sejam objeto de providências imediatas para a sua plena e integral execução. Rio de Janeiro, 3 de maio de 1957.

Barreto Guimarães - (Deputado Estadual, Delegado dz Pernambuco ao IV Congresso dos Municipios Brasileiros, Rio de Janeiro 3 de maio de 1957). 
Observação: $O V$ Congresso Nacional dos Municipios, realizado na cidade do Recife, em Pernambuco, de $1^{\circ}$ a 8 de dezembro de 1959 renovou e homologou todos os pronunciamentos favorátris à Operação Municipio aprovados pelos Congressos anteriores. Além disso, o referido Congresso aprovou e votou novas Recomendações sôbre a matéria, reafitmando que a Operação Municipio dizve ser considerada como - objetivo supremo do Movimento Municipalista e destarte, a Reivindicação prioritária das Prefeituras e Câmaras de todo - Brasil como instrumento decisivo da luta contra o subdesenvolvimento e o pauperismo. (Nota da Redação).

1 - DISPÕE SÔBRE AS BASES E DIRETRIZES PARA A ORGANIZAÇÃo DO PLANO NACIONAL DE OBRAS E SERVIÇOS MUNICIPAIS

\section{(OPERAÇÃo MUNICÍPIO)}

Congresso Nacional decreta:

Art. 1\% Ficam estabelecidas as bases e diretrizes para a organização do Plano Nacional de Obras e Serviços Municipais - (Operação Município) - objeto da Recomendação Especial aprovada no III Congresso Nacional de Municipios, realizado em São Lourenço, Minas Gerais, entre 15 e 22 de maio de 1954.

Parágrafo único. O Plano de que trata o artigo será executado em 5 exercícios consecutivos, pelo regime de cooperação e convênio entre a União e os Municípios que ao mesmo aderirem, obedecidos os princípios e normas fundamentais consubstanciadas na presente Lei.

Art. 2: O Plano Nacional de Obras e Serviços Municipais (Operação Municipio) terá como objetivo principal promover o desenvolvimento econômico-social dos Municipios brasileiros, de maneira que os transforme em unidades de sustentação do progresso econômico-social do País, especialmente em seus aspectos agrícola, industrial, preservação da saúde pública, ditusão do ensino técnico-profissional, aparelhamento para os transportes e comunicações, e produção de energia.

$\S 1$ o Objetivo visado no artigo deverá ser alcançado mediante:

I - a criação da Comissão Nacional Organizadora do Plano;

II - a votação, em lei especial, do Fundo Financeiro, constituído de recursos vinculados às obras, serviços e demais empreendimentos a serem computados no Plano;

III - a criação da Comissão Nacional Executiva do Plano, cuja organização deverá ser pautada nos moldes da Administração do Plano Salte;

IV - a assinatura de convênios nos quais fique estabelecida, tanto quanto possivel, a descentralização administrativa mitigada, reservando-se à União a orientação e o contrôle técnico dos respectivos projetos, de modo que se ressalve a aplicação dos recursos na forma prevista pela Presente Lei e atos que lhe foram subseqüentes ou complementares; 
$\mathrm{V}$ - a votação de lei especial relativa ao sistema financeiro da execução do Plano, atendidos os fundamentos que presidem o da execução do Plano Salte;

VI - a formulação do projeto do Plano (Lei de Programa) pela Comissão Nacional Organizadora do mesmo, a fim de que seja encaminhada ao Congresso para votação de lei especial, integrada pelas tabelas descriminativas das obras, serviços e demais empreendimentos a serem atendidos;

$\S 2$ ? $\mathrm{O}$ projeto referido no item IV do parágrafo anterior deverá conter:

a) a consignação de recursos para o início, até conclusão, de obras e serviços públicos imprescindiveis às áreas municipais, especialmente no setor rural;

b) a consignação de recursos para o prosseguimento ou a complementação de obras e serviços públicos existentes nos municipios, e a êstes pertencentes; ou de outros, executados pela União, cuja entrega às administrações municipais será feita na forma e nos têrmos que a lei determinar;

c) a consignação de recursos para serem entregues, a titulo de auxilio, às entidades privadas, cujas finalidades digam respeito a serviços de educação e saúde ou de prestação de assistência social a título gratuito; bem como a serviços cooperativos, se destinados a obras de melhoramentos e instalações, segundo programa qüinqüenal prèviamente estabelecido para inclusão no Plano objeto da presente Lei.

d) consignação de recursos para estudos, projetos e respectiva implantação de reformas administrativas destinadas a racionalizarem o aparelho administrativo das Prefeituras, incluindo-se nas mesmas a de reorganização dos serviços de secretaria das Câmaras de Vereadores, bem com formulação de anteprojetos de leis e regulamentos destinados a suprirem deficiências ou a aparefeiçoarem as atividades municipais;

e) consignação de recursos para o estabelecimento, em larga escala. do sistema de revenda de materiais e equipamentos agrícolas aos pequenos lavradores, por intermédio das Prefeituras, ou das entidades cooperativas locais, mediante a assinatura de convênios especiais com a União;

f) consignação de recursos para a concessão de "bôlsas de estudo" às administrações municipais para a formação, especialização e aperfeiçoamento de pessoal; para a formação, especialização e aperfeiçoamento técnicoprofissional concernente ao trabalho na agricultura, indústria e comércio; para a formação, especialização e aperfeiçoamento de pessoal destinado a centros, hospitais e demais serviços de saúde; estabelecimentos de ensino rural-industrial de qualquer natureza, mediante a assinatura de acôrdos especiais entre a União, os Municipios e as entidades competentes, neste último caso se as respectivas entidades não forem serviços da primeira;

g) consignação de recursos para a execução de melhoramentos urbanos, desde que vinculados à saúde e higiene das populações.

Art. 3: Os recursos para quaisquer serviços obras ou empreendimentos convencionados serão sempre concedidos nas proporções de $90 \%, 70 \%$ e $50 \%$ por parte da União, e os restantes $10 \%, 30 \%$ e $50 \%$ como contribuições do Municipio. 
$\S 1^{\circ}$ A lei financeira referida no item $\mathrm{V}$ do artigo $2^{\circ}$ fixará as proporções estipuladas neste artigo tomando por base as seguintes prioridades para maior contribuição da União em relação a cada projeto:

a) maior rentabilidade;

b) maior interêsse econômico, nacional, regional, municipal;

c) maior interêsse social;

d) menor renda municipal.

$\S 2$. As contribuições do Municipio poderão ser estabelecidas nos respectivos convênios sob formas que não a financeira.

$\S 3$ 3 Os Estados, se assim o entenderem, poderão aderir técnica e financeiramente aos objetivos na parte relativa aos empreendimentos, obras e serviços intermunicipais cujas proporções venham a exceder à capacidade de contribuição das áreas municipais interessadas.

Art. 4. As obras e serviços públicos a que se referem as letras $a, b$ e $g$ do $\S 2^{\circ}$ do artigo $2^{\circ}$, são as seguintes:

a) rodovias, inclusive obras d'arte desde que não prevista nos Planos Rodoviários Nacional e Estaduais, e destinados a ligações intra ou intermunicipais, neste último caso à base de prévio acôrdo entre os interessados;

b) centros, hospitais e demais serviços de saúde pública;

c) postos, núcleos agropecuários e demais serviços agrícolas relacionados com o melhor aproveitamento das riquezas vegetal e animal;

d) obras e serviços relacionados com a pesca e melhoria das condições de vida dos pescadores e de suas familias;

e) pequenas unidades industriais destinadas a promoverem o beneficiamento ou maior aproveitamento econômico da produção local;

f) construção de pequenas usinas de produção de energia para consumo local, ou de algumas áreas municipais, neste último caso à base de prévio acôrdo entre os interessados; irrigação;

g) construção de açudes, barragens, reprêsas, obras e sistemas de

h) obras de saneamento, desobstrução e limpeza de rios, construção de canais;

i) construção e instalação de escolas, especialmente rurais, inclusive promoção de cursos avulsos, para a formação de profissionais;

j) obras e serviços de águas e esgotos, bem como de saneamento de áreas urbanas e suburbanas.

Art. 5\% A municipalização de serviços é princípio dominante na organização dos projetos do Plano e fundamento para a transferência de serviços à alçada das Prefeituras.

Art. 6? Para o efeito do Plano são "benéficos de ordem rural" os destinados à melhoria das condições de vida das populações do campo e da produção nas áreas urbanas e suburbanas das sedes e dos distritos municipais.

Parágrafo único. A semelhança, analogia ou equivalência entre uns e outros não prejudica aos primeiros, desde que localizados nas áreas a que se referem. 
Art. 7० As aquisições de materiais e equipamentos para revenda aos pequenos agricultores serão feitas por encomendas globais da Administração do Plano e entregues às Prefeituras ou entidades cooperativas locais, conforme programas prèviamente estabelecidos nos convênios especiais firmados com a Uniño.

Art. 8: A adesão do Municipio ao Plano importa a aceitação das bases e diretrizes desta lei, bem como dos princípios, fundamentais, normas e processos estabelecidos nas que lhe seguirem.

Art. 9: Fica o Poder Executivo autorizado a organizar os projetos relativos aos instrumentos legais, mencionados nos itens II a VI do $\S 1^{\circ}$ do artigo $2^{\circ}$, bem como a baixar os atos de constituição da Comissão Nacional Organizadora do Plano, objeto do item I do mesmo parágrafo e artigo.

Art. 10. A Comissão Nacional Organizadora do Plano será constituida de cinco (5) Membros e de um Assessor Principal, nomeados por decreto do Presidente da República, sendo que o último, por indicação, em lista tríplice, da Associação Brasileira de Municípios.

Parágrafo único. O Assessor Principal reunirá a qualidade de Diretor Executivo da Comissão.

Art. 11. Fica autorizada, pelo Ministério da Justiça e Negócios Interiores, abrir o crédito especial de Cr\$ 5.000.000,00 (cinco milhões de cruzeiros) para os trabalhos da Comissão Nacional Organizadora do Plano.

Art. 12. Esta lei entrará em vigor na data de sua publicação, revogadas as disposições em contrário.

Sala das Sessões, em 24 de junho de 1954. — Jarbas Maranhão.

\section{2 - OPERAÇ̃̃o MUNICÍPIO}

\section{Justificação}

Com êste projeto de lei damos uma demonstração positiva de quanto atentamos para as reivindicações aprovadas pelo III Congresso Nacional de Municípios, realizado em São Lourenço, Minas Gerais, entre 15 e 22 de maio do corrente ano.

Entre aquelas, e como a consubstanciar tôdas aspirações do Município brasileiro cabe destacar, por sua importância e repercussão no seio das delegações que compareceram ao conclave, a referente à Operação Município - organização e estabelecimento de um Plano Nacional de Obras e Serviços Municipais, a ser executado mediante convênio entre a União e os Municipios, tendo por base um Fundo Financeiro próprio e Administração Especial do tipo do Plano Salte.

A Operação Município em que se consubstancia o referido Plano foi, como dissemos, objeto de uma Recomendação Especial votada pela unanimidade das delegações presentes ao III Congresso Nacional de Municípios.

Pareceu-nos, assim, oportuno, formular projeto de lei através do qual sejam fixadas as bases e diretrizes para a organização do Plano em aprêçr. 
a fim de que venha a mesma a corresponder - não só aos interêsses indispensáveis a instrumento legal de sua envergadura.

Dêsse modo, além de definirmos o Plano; dizemos de sua duração e processo geral de execução (convênios e acôrdos, sistema de cooperação); estabelecemos o seu propósito principal, relacionamos os instrumentos legais necessários à sua formulação e existência; relacionamos a natureza dos serviços, obras e empreendimentos a se atender; autorizamos o Poder Executivo a nomear a respectiva Comissão Nacional Organizadora e a abrir o crédito especial recessário aos trabalhos desta última.

Se êsses trabalhos forem realizados à base das diretrizes que aqui estabelecemos, serão não só facilitados como contarão, por outro lado, com a ordem lógica indispensável a todo planejamento.

Justifica-se, pois, a nossa convicção de que, ao submetermos êste projeto à consideração desta Casa, correspondemos ao desejo comum de demonstrarmos o quanto estivemos atentos à palavra de ordem do homem do interior, consubstanciada na Recomendação Especial aprovada no III Congresso Nacional de Municípios.

Para maior esclarecimento em tôrno da matéria, pronunciaremos, dentre de breves dias, discurso no Plenário desta Casa, através do qual assinalaremos mais a fundo a imperiosa necessidade econômico-social de formulação do Plano Nacional de Obras e Serviços Municipais - a indispensável Operação Município.

Anexo a esta justificação juntamos os documentos básicos, preliminares. em tôrno do Plano, cujas diretrizes traçamos neste Projeto.

Sala das Sessões, em 24 de junho de 1954. - Jarbas Maranhão

\section{3 - OPERAÇÃO MUNICÍPIO}

A recomendação relativa ao "Plano Nacional de Obras e Serviços Municipais", aprovada pelo III Congresso Nacional de Municípios.

Luciano F. Mesquita Membro do Conselho Deliberativo da Associação Brasileira de Municipios. Assessor Técnico da Comissão de Finanças do Senado Federal.

1. Nota explicativa. 2. O Projeto de Recomendação, documento $n^{2}$ 66, apresentado ao III Congresso Nacional de Municípios. 3. Os pareceres: a) Araújo Cavalcanti; b) Delorenzo Neto; c) Manoel Ferreira de Melo; d) Comissões de Planificação Municipal e da Carta de São Vicente; (itens $3^{\circ}$ e $5^{\circ}$ do Temário) 4. Conclusão.

\section{Nota Explicativa}

projeto de recomendação que a seguir publicamos, foi aprovado, por unanimidade, com emenda e subemenda adiante transcritas, pelo III CongresSo Nacional de Municipios, realizado em São Lourenço, Minas Gerais, entre 15 e 22 de maio do corrente ano. 
A emenda, conforme é possivel verificar-se pelo texto, consubstancia o propósito fundamental da recomendação e assinala os caracteres básicos do instrumento ao qual se refere.

A emenda foi apresentada pelo Dr. Lourival Batista, Prefeito de São Cristovam, Sergipe, e contou com a assinatura de cêrca de oitenta representantes de municipios de todos os Estados. Êle veio a constituir o artigo 1. da Recomendação Especial aprovada pelo Congresso, assim redigido:

Artigo $1^{\circ}$ Organização e Estabelecimento de um Plano Nacional de Obras e Serviços Municipais, com Fundo Financeiro próprio e Administração especial aprovado em prévio acôrdo interpartidário específico para ser executado mediante convênio, devendo os governos municipais, estaduais e federal se entenderem para o fim colimado nessa recomendação.

À emenda foi apresentada subemenda que consubstancia o artigo $2 .^{\circ}$ da Recomendação, assim redigido:

Art. 2: Enquanto não fôr elaborada e incorporada ao Orçamento da União a Operação Município (Plano Nacional de Obras e Serviços Municipais), os Prefeitos e Vereadores do Brasil, reunidos no Congresso de São Lourenço, reivindicam um Programa de Emergência na ordem de 3 bilhões de cruzeiros ( $\mathrm{Cr} \$ 3.000 .000 .000,00$ ) como antecipação do investimento total da Operação-Municipio, solicitando ao Govêrno Federal a abertura de crédito especial competente.

Convém esclarecer que apresentamos a recomendação na forma dos dez itens que a seguir transcrevemos - não por considerarmos os processos ali indicados como sendo os melhores e os mais viáveis - mas porque tivemos em vista a necessidade de se desplertar as atenções dos Congressistas para o fato de que o Plano ao qual o mesmo se reportava deveria ser, por um lado, o resultado de conciente e determinado acêrto político de caráter nacional e, por outro, o fruto de congregado esfôrço dos três níveis de govêrno, sem os quais, digamos de passagem e com sinceridade, não acreditamos em nenhum plano desta ordem.

A aprovação do projeto segundo a sintese da emenda facilitará, por certo, o encaminhamento das medidas destinadas a movimentarem o pais para a organização do Plano. Estas medidas, como dissemos, poderão ser outras, mais simples, mais diretas, embora jamais devam deixar de refletir processos de mitigada descentralização.

Portanto, a sintese configurada pelo artigo $1^{\circ}$ da Recomendação, ao invés de esmaecer o caráter político da manifestação do III Congresso Nacional de Municipios, acentuou-o, traduzindo, em pouquíssimas palavras, o pensamento dos municípios brasileiros, que, ao país, disseram simplesmente o seguinte:

a) que acham viável a organização e estabelecimento de um Plano Nacional de Obras e Serviços Municipais;

b) que consideram imprescindivel o instrumento em aprêço para o racional emprêgo de recursos no interior do país; 
c) que consideram o sistema de convênio o mais adequado a êsse tipo de cooperação inter-governamental e à execução de obras e serviços que se venham a refletir na economia nacional;

d) que consideram ser necessário venha o Plano a contar com recursos financeiros especiais e administração autônoma de maneira a tornar possivel a sua execução sem pertubações nos orçamentos ordinários do país;

e) que julgam imprescindivel, para êsse fim, a assinatura de um acôrdo inter-partidário especifico, destinado a excluir das competições as obras e serviços a se programar;

f) que, finalmente - através do artigo $2^{\circ}$ (subemenda) - aguardam providências de emergência, enquanto não fôr elaborado o Plano recomendado.

Se as autoridades públicas - e os partidos políticos nacionais - atentarem para a recomendação votada pelo III Congresso Nacional de Municipios, e resolverem transformá-la em realidade, estamos certos, seguros, de que prestarão assinalados serviços ao país em geral, e aos municípios em particular, pois, com o Plano criarão o instrumento legal adequado a solução de inúmeros pequenos problemas de interêsse nacional. cujo encaminhamento tem sido difícil justamente à falta daquele.

É que a denominada "Operação-Município - que tanto deu que falar - conforme sintese publicada e distribuída no seio do prôprio Congresso de São Lourenço, nada mais é que um Plano Nacional de Obras e Serviços Municipais cujo sentido e finalidade é o de forçar investimentos na direção de interior, especialmente no setor rural e naqueles que com êste se relaciona, seja porque ajudarão o seu desenvolvimento, seja porque importam em matéria complementar à vitalização das atividades rurais, as quais, se constituem em base de sustentação para o desenvolvimento econômico-social do país em geral, especialmente em relação à indústria e demais atividades de sentido tecnológico.

Repousando politicamente num Acôrdo Interpartidário Específico, e devendo ser administrado e executado pelo sistema de convênio, representa uma sugestão vinda do interior no sentido de que seja desenvolvido um esfôtço honesto por parte das autoridades públicas brasileiras, em favor da vitalização das atividades econômicas, mas nem por isso menos imprescindiveis, que se enriquecimento efetivo real, das numerosas comunidades brasileiras, quer à debelação da crise econômica que estamos enfrentando com pequenos resultados.

Não será inflacionário - e mesmo contra a inflação monetária se dirige - em virtude de se propor a canalizar substanciais recursos para as atividades que não são as fomentadoras do citado fenômeno financeiro. Por outro lado, dado a sua estrutura e meios de formação, deveria ser instrumento destinado a descobrir os orçamentos estaduais, e o federal, de obras e serviços de peculiar interêsse dos Municípios, obras e serviços êsses que necessàriamente vêm sobrecarregando os referidos instrumentos em virtude dos seguintes fatôres: $1 .^{\circ}$ ) falta de recursos criteriosar ente distribuidos nas áreas mutnicipais, visto faltar à maioria delas assistên ia técnica para a aplicação racional dos mesmos; $\left.2 .^{\circ}\right)$ falta de outro instı imento legal, nos setores estaduais e federal, que possibilite a ajuda requerida pelos Municípios. 
Finalmente, por sua própria natureza, em país como o nosso, economicamente em fase de desenvolvimento, o Plano representa ponto dos mais autênticos de qualquer programa de govêrno realmente formulado à base das necessidades nacionais.

Através os municípios brasileiros conclamam a Nação a um esfôrço fecundo e para cuja execução não é possivvel haver mais dilação.

Para concluir, é preciso dizer, nesta nota, que a Recomendação foi aprovada pela unânime manifestação dos municipios de todo o pais, destacando-se por ter merecido o apoio declarado de homens como o Sr. Jorge Arbix, Prefeito de Americana, no Estado de São Paulo, que figurava entre os que mais the resistiam. O destaque que fazemos dêsse fato importa em assinalar o nosso sincero reconhecimento a todos que, como o citado representante de Americana, souberam - revelando espírito público e pondo de lado as paixões momentâneas - deliberou em favor dos interêsses nacionais e, portanto, dos interêsses dos municipios ali representados.

O Sr. Jorge Arbix, Prefeito de Americana, no Estado de São Paulo, não sòmente se opôs tenazmente ao projeto, como procurou estudá-lo, como tudo promoveu no sentido de obter para sí próprio e para os companheiros da Comissão esclarecimentos em tôrno de detalhes que, evidentemente não poderiam figurar, quer no texto da recomendação. quer na justificação da mesma.

Mas, uma vez esclarecido, e como nos outros também convencido de ser o Plano meio seguro para um esfôrço positivo na direção das soluções brasileiras de caráter municipal, o Sr. Prefeito de Americana deu exemplo de alta elevação quando, na sessão plenária, convocou os seus companheiros de bancada a votarem em favor do projeto, mesmo sob a presunção - como êle próprio disse - de que o seu municipio não venha a ser muito beneficiado pela idéia, dado tratar-se de área industrial, cuja riqueza talvez possa determinar a sua exclusão do projeto.

2. O Projeto de Recomendação, documento $n^{\circ} 66$, apresentado ao III Congresso Nacional de Municípios.

\title{
4 - OPERAÇÃO MUNIĆ́PIO
}

\author{
PROJETO DE RECOMENDAÇÃO
}

Dispõe sôbre as medidas preliminares para a organização e o estabizlecimento de um Plano Nacional de Obras e Serviços Municipais a ser executado mediante Convênio entre a União, os Estados e Municipios.

O III Congresso Nacional de Municípios, realizado entre 15 e 22 de maio de 1954, na cidade de S. J Lourenço, Municipio do mesmo nome, no Estado de Minas Gerais. 
Considerando que os problemas das municipalidades brasileiras sob muitos aspectos se entrozam com os dos Estados e os da União;

Considerando que, por outro lado, os problemas dessas municipalidades se apresentam de tal maneira no conjunto das mesmas que é possivel dar-lhes soluções integradas capazes de serem formuladas segundo denominadores comuns que poderão ser objeto de um plano nacional de obras é serviços municipais;

Considerando que há interêsse nacional em se dar solução equilibrada aos referidos problemas, sem que dai decorram dificuldades maiores para o desenvolvimento econômico social do país e de suas regiões geo-econômicas;

Considerando que o fortalecimento econômico-social dos municipios constitui tarefa complementar e concomitante ao alcance dos demais:

Considerando que as reivindicações municipalistas expressas nas Cartas de Petrópolis e de São Vicente necessitam ser traduzidas em instrumentos legais de ação positiva, sendo o já referido Plano um dêsses instrumentos; e

Considerando, afinal, que a falta de tais instrumentos é que tem determinado a desorientação e o desperdicio de recursos e esforços preciosos que se bem canalizados e aproveitados, oferecerão rendimento até o momento não conseguido.

\section{Recomenda}

I - Aos Partidos Politicos Nacionais que promovam e assinem logo após as eleições de 3 de outubro e, ainda êste ano - um Acôrdo Interpartidário Específico, destinado a comprometer os seus associados no estabelecimento e execução de um Plano Nacional de Obras e Serviços Municipais, cujas autorizações fiquem acima das naturais e necessárias lutas partidárias em tôrno de outros problemas nacionais, regionais e locais;

II - Aos Prefeitos Municipais face ao assentado no referido Acôrdo, e em pleno entendimento com as Câmaras de Vereadores, que nomeiem, em janeiro de 1955 numa demonstração unissona da unidade do movimento municipalista e da fôrça de seus Congressos uma Comissão de três (3) membros cuja atribuição seja a de elaborar um programa preliminar de obras e serviços de seu peculiar interêsse para ser computado no Plano Nacional, objeto desta recomendação;

III - Aos Prefeitos Municipais que, de posse dêsses programas os enviem aos Governadores de seus respectivos Estados, a fim de que êsses, no máximo até 15 de abril de 1955 , em solenidade pública acusem o recebimento dos mesmos e concomitantemente, nomeiem uma Comissão de três (3) a cinco (5) membros cuja atribuição seja a de integrar uns programas nos outros, mediante a previsão das obras e serviços intermunicipais julgados necessários à formulação do Plano Estadual de Obras e Serviços Municipais e Intermunicipais a ser submetido, com mensagem, às respectivas Assembléias Legislativas;

IV - As Assembléias Legislativas que, uma vez recebida a Mensagem dos Governadores, votem o respectivo projeto de lei, de maneira a ser possi- 
vel aos segundos remeterem o diploma aprovado acompanhado dos dossiers justificativos ao Presidente da República, nos últimos dias de agôsto ou primeiros de setembro, de forma a que seja possivel a êste último em solenidade pública, a 7 de setembro de 1955 , comunicar à Nação o recebimento dos mesmos e a nomeação da Comissão Especial de Planejamento incumbida de elaborar o projeto do Plano Nacional de Obras e Serviços Municipais a ser submetido ao Congresso Nacional no dia 15 de março de 1956, data da abertura da sessão legislativa ordinária relativa ao citado ano;

$\mathrm{V}$ - Ao Congresso Nacional que, uma vez recebido o projeto do Poder Executivo, o vote fundamentando tanto quanto possivel as emendas que por ventura oferecer em sugestões provindas das autoridades municipais e estaduais interessadas ouvida a Comissão Especial de Planejamento;

VI - Às Câmaras de Vereadores, às Assembléias Legislativas e ao Congresso Nacional que propiciem aos Prefeitos, aos Governadores e ao Presidente da República os recursos financeiros indispensáveis aos trabalhos das Comissões incumbidas de elaborarem o Plano em suas diversas fases, a fim de que estas os façam com o devido cuidado técnico;

VII - Às Câmaras de Vereadores e às Assembléias Legislativas, em comum acôrdo com os Prefeitos e os Governadores, que votem leis especiais objetivando o levantamento dos recursos necessários à formação do Fundo Nacional para a execução do Plano, sempre que possivel ouvido o Conselho Técnico de Economia e Finanças do Ministério da Fazenda e o Departamento Ādministrativo do Serviço Público;

VIII - Às Câmaras de Vereadores e às Assembléias Legislativas, que no item anterior no período compreendido entre janeiro de 1955 e janeiro de 1956, de maneira a ser possivel ao Presidente da República enviar ao Congresso Nacional trinta (30) dias após a abertura da sessão legislativa ordinária de 1956, projeto de lei dispondo sôbre a criação do Fundo Nacional para a execução do Plano, ao qual sejam previstas as fontes da contribuição federal;

IX - Aos Governos Municipais, Estaduais e Federal que, uma vez votadas as leis federais relativas ao Plano e ao Fundo, assinem os convênios necessários à execução das mesmas, instituindo para êsse fim um órgão convenial de orientação, consulta e contrôle para a execução do Plano. obrigatòriamente constituído de uma Administração Nacional e tantas estaduais quantos fôrem os Estados;

X - A Associação Brasileira de Municipios que: 1\%) Preste aos podêres públicos empenhados em dar execução às diretrizes desta Recomendação a maior assistência possível; $2^{\circ}$ ) Formule e prepare o anteprojeto da organização do órgão convencional de orientação, consulta e contrôle referido no item anterior a fim de oferecê-lo aos poderes públicos como contribuição sua; $3^{\circ}$ ) Planeje e prepare um dosșier relativo à forma e processos de funcionamento e ação do mencionado órgão de sorte a propiciar o imediato funcionamento, do mesmo logo após a sua criação, ressalvadas as suas modificações aprovadas pelos poderes públicos. 


\section{Justificação}

Em trabalho que escrevemos na Rlıvista do Serviço $P$ úblico de maio do corrente ano, número especialmente dedicado aos debates de questões municipalistas, tivemos a oportunidade de sugerir fôsse objeto das atenções do III Congresso Nacional de Municipio e, portanto, objeto de recomendação sua aos governos Federal, Estaduais e Municipais, o encaminhamento das medidas preliminares necessárias à organização e formulação de um plano nacional de obras e serviços municipais.

Dissemos que êsse plano deveria ser prèviamente apoiado por um Acôrdo Interpartidário Especifico. destinado a possibilitar a votação de leis especiais nos âmbitos federal, estadual e municipal, autorizando a execução do referido plano, mediante o sistema de Convênios entre a União, os Estados e os Municípios.

Dêsse modo dando forma prática à idéia que lançamos no mencionado trabalho, e tendo por objetivo único facilitar, quer as decisões e manifestações do II Congresso Nacional de Municipios a respeito da matéria, quer as providências decorrentes de tais decisões e manifestações no campo administrativo-governamental dos três niveis de governo, oferecemos ao debate dêste Congresso o projeto de recomendação que a esta exposição acompanha, em a qual procuramos estabelecer as diretrizes e as bases para as citadas providências.

Como é de ver, a Recomendação a ser votada importará em instrumento orientador dos governos federal, estaduais e municipais; dos partidos politi$\cos$; das associações de municipios e demais entidades que, embora não citadas expressamente, de fato se interessam pelas soluções nacionais destinadas à promoção do bem-estar social, que no caso, inclui o conceito de melhoramento econômico.

Como a idéia que formulamos, assim como a recomendação que neste momento sugerimos necessitem ser apoiadas em fundamentos que não as transformem em mais uma idéia e mais uma recomendação, tudo fizemos no sentido de propormos declaração simples mas objetiva. E, que, além de simples e objetiva, repercute nos meios interessados como instrumento capaz de não só sugerir, como também ordenar as providências e medidas em tôrno do grave problema do fortalecimento do municipio brasileiro segundo critérios mais ou menos uniformes quanto aos aspectos formais das mesmas.

A Campanha Municipalista já ultrapassou a chamada "fase heróica". Esta fase foi da maior importância para a eclosão e afirmação do magnífico movimento cuja vitalidade temos para atestar êsse mesmo Congresso do qual participamos. Mas, com o III Congresso Nacional de Municipios, cremos que já é tempo de darmos início a uma nova fase cujo sentido fundamental há de ser o de passarmos do terreno das reivindicações - que à falta de outro têrmo denominaremos de juridico ideais - para as de natureza juridicoconcretas, as quais devem ser evidentemente sempre obtidas através de diplo- 
mas legais adequados, tais como sejam, convênios, leis e mais peças criadoras de organismos vivos, a saber, planos acompanhados de recursos próprios com administração própria, assentados em bases realisticas, porque alicerçados em idéias passiveis de manipulação objiztiva.

Todos nós sabemos que a imaginação nacional é um tanto efervescente e por isso muitas vêzes ligeira. Constitui, assim dever precipuo dos homens que influenciam, orientam e comandam a vida brasileira, não só domarem a imaginação própria, aquela de que são portadores, como tudo fazerem no sentido de que, as que lhes cercam, sintam-se inclinadas a também se sofrearem, de modo a permitir que, as soluções propostas para os problemas de ordem prática, tragam o cunho da viabilidade, a fim de não permanecerem entre as destinadas ao fatal fracasso, justamente porque não foram escoradas em alicerces seguros, fruto e resultado de acurada meditação por parte daqueles que as promoveram.

Um plano nacional de obras e serviços municipais não é emprêsa de fácil realização. E emprêsa complexa, mas, nem por isso impossivel, se produto, se resultado de organizada e prudente preparação. Julgamos que a esta preparação disciplinamos através do projeto. Por seu intermédio, recomendamos não sòmente os instrumentos básicos, mas também os processos e o tempo relativo à elaboração daqueles evidentemente que, como é de se fazer num Congresso, traçando-se apenas as diretrizes.

Referimo-nos a plano nacional, fruto de prévio Acôrdo Interpartidário Especifico, executado mediante convênios, com administração e recursos próprios, contando com as leis convenientes, em virtude de havermos considerado, entre outros pontos os seguintes:

A) que os problemas das municipalidades brasileiras são comuns a quase tôdas apesar dos desníveis evidentes entre umas e outras; isto é, são problemas de:

1) Técnica da Administração Municipal;

2) Saúde;

3) Educação;

4) Transportes e Comunicações;

5) Energia;

6) Produção Agropecuária e Industrial; todos mais ou menos reduziveis, no âmbito municipal, a denominadores comuns e por conseguinte, suceptíveis de serem equacionados em um plano nacional, que a tôdas as municipalidades beneficie naquilo que a cada uma interessar da maneira premente.

B) que o tratamento dos citados problemas não tem sido objeto de diretrizes firmes e positivas, não obstante o sabermos básico, fundamental, nara o melhoramento e o bem-estar gerais, inclusive porque seria ponto de 
partida e meio seguro de eliminar-se a série de repercussões negativas hoje assinaladas nos grandes centros populacionais e produtores, e advindas, provocadas pelo constante e crescente agravamento das condições de vida no interior do Pais.

C) que devemos o apontado no item $B$ a inúmeros fatôres, entre os quais podemos citar os seguintes:

1) politização demasiada em tôrno de soluções municipais de caráter imprescindivel as quais, na forma do que pensamos, se devem constituir em problemas para cujo encaminhamento os diversos partidos politicos nacionais devem chegar a um acôtdo, sejam quais forem as correntes dominantes; pois se trata de questões a exigirem um minimo de atritos e um mínimo de desperdicios, sem os quais jamais os municipios verão as suas aspirações minimas e justas realmente concretizadas; não por culpa dêste ou daquele partido; não por culpa dêsse ou daquele governante ou dirigente administrativo mas por culpa de todos;

2) . desorientação quanto ao modo de encaminhar-se as soluções, e mal emprêgo dos recursos disponiveis ou dirigidos a fins municipais ou a êstes correlacionados, tal como se pode verificar através da inclusão, nos orçamentos públicos, especialmente o federal, de cotações de tôda sorte e natureza (e até sem sorte e natureza), resultando disso grande sacrifício, quer para o orientado desenvolvimento econômico do país, quer para a boa ordem das finanças públicas dos três níveis de govêrno.

É o desperdício de recursos. É a inconstância na consignação e na liberação dos mesmos. É a criação de novos serviços em detrimento de outros já criados. É o abandono dêstes últimos e o não prosseguimento dos primiros, tudo isso com recursos federais subtraidos a atividades federais e, sem o mérito, pelo menos, de resolver o que se pretende resolver.

É que tais soluções são manifestamente de natureza técnico-administrativa, a exigirem a menor interferência possivel de critérios politicos;

3) falta de organização administrativa adequada, capaz de assegurar aos municípios a assistência técnica indispensável tanto no emprêgo dos meios que lhes são próprios, como no emprêgo daqueles que lhes são deferidos diretamente ou a entidades que nêles vivem intentando e prestando serviços (auxílios e subvenções).

Nessas condições, parecemos mais do que indicado que as soluções relativas aos pequenos, mas ainda assim graves problemas de nossas municipalidades venham a ser objeto de um plano nacional de obras e serviços que seja pelo menos, uma tentativa preliminar de esfôrço sério, construtivo. Sem êsse plano não acreditamos na efetiva capacidade de expansão de economia brasileira, pois, um dia há de chegar em que esta verse-á em dificuldades quase intransponiveis para sair dos gargalos pelos quais enveredou.

Até aí está tudo muito bem. Mas, como conseguirmos êsse plano com o mínimo de atritos e o mínimo de desperdícios a que nos referimos? Como orientarmos o processo da ação governamental? Como sairmos daqui dêsse Congresso, levando pelo menos a convicção de que nos reunimos para propor alguma coisa útil? Como sairmos daqui levando as diretrizes que facilitem inclusive os nossos próprios movimentos? 
Eis o sentido do projeto que vos submetemos. Pelos seus têrmos verifica-se que procuramos dar apenas um roteiro a respeito das providências de modo a que as mesmas não só sejam tomadas simultâneamente em todos os municípios e Estados, como tenham certo caráter de unidade formal.

Fugimos de disciplinar o que não pode ser uniformizado.

Se a Recomendação contivesse dispositivos sôbre as fontes de recursos às quais os municipios deverão recorrer para a constituição do Fundo, estaríamos a propor o impossivel, pois não pode haver uniformidade em relação a êsse pento. A composição e a estrutura econômico financeira de cada municipio e de cada Estado e que dirão quais serão essas fontes.

A idéia central do plano e a de que tudo deve ser feito dentro das possibilidades de cada área municipal e estadual e proporcionalmente a tais pcssibilidades. Por isso mesmo, também quanto às despesas, nada procuramos recomendar, visto que essas nada mais serão que o cálculo, em dinheiro, dos serviços e obras programadas.

Dir-se-á que faltará capacidade técnica, senso de escolha, e até mesmo imaginação por parte de inúmeros municipios para a formulação de um programa daquilo que realmente necessitam. Não cremos que êsse argumiento valha de um modo geral. Mas, mesmo admitindo-se que tal aconteça, note-se que, na Recomendação, referimo-nos a programas preliminares, importando isso em dizer-se que os mesmos poderão ser ajustados e avaliados posteriormente, quando na confecção do Plano no âmbito federal.

A Comissão Especial de Planejamento (prevista no item V da Recomenciação) é que caberá a decisão de caráter técnico a respeito da utilidade e da viabilidade dos projetos, embora não lhe deva competir alterar a idéia fundamental, ou as idéias fundamentais, do programa a ser executado em cada município.

A idéia política central da Recomendação e, portanto, do Plano que dela surgir, é $\cdot a$ de que os municípios - embora melhor dotados a partir das quotas constitucionais de que participam, e apesar de tôdas as emendas orçamentárias formuladas pelos congressistas nos Orçamentos Federais - não estão sendo beneficiados no sentido do desenvolvimento econômico-social. O que há, sobretudo, é desperdício e dispersão. E para um e outra o Govêrno Federal paradoxalmente contribuindo, em virtude de faltar-lhe os instrumentos que o ponham em condições de orientar o problema.

Dêsse modo, é indispensável que os próprios municípios o ajudem na turefa, oferecendo-lhe e, bem assim, aos governos estaduais, a fórmula capaz de melhor orientar as providências na direção do auxílio e assistência que ambos lhes querem dar.

O Plano viria, por outro lado, desafogar os orçamentos públicos ordinários, em os quais inúmeras despesas são computadas em virtude de não existir outro instrumento para financiá-las.

Os municípios querem e necessitam as ajudas federal e estadual. Mas estamos certos, as querem e preferem de maneira ordenada.

O homem do interior ante a balbúrdia reinante a respeito da matéria, é levado mais a desacreditar que outra coisa. Daí, muitas vêzes, o seu justifi- 
cado desinterêsse. Êle sabe que não é o que se propõe ou promete, que virá resolver coisa alguma. Ele conhece melhor do que ninguém o que e de que necessita. De fora necessita e quer assistência técnica; interêsse para que as soluçóes que êle conhece sejam dadas segundo a sua melhor forma. A respeito dessa forma é que, muitas vêzes, êle tem idéias obscuras, resultando daí tôdas as dificuldades para o preciso encaminhamento das providências em tôrno de suas necessidades. À União e aos Estados o que compete, pois, é ouvi-lo, é auscultar-lhe as necessidades, traduzindo-as de modo claro.

Por conseguinte, a existência do Plano a partir de suas próprias idéias, das do homem do interior, a partir do que êle conhece e sente ser necessário à sua terra, será para êle um modo de vir a acreditar e se afirmar e, para os niveis mais altos do govêrno, um processo seguro de ação.

Se, ao contrário, o Plano nascer, surgir das celebrações burocráticas dos gabinetes, se os problemas das municipalidades forem tratados como se de cúpula fôssem, isto e, a partir de cima, então o melhor será continuarmos como estamos, posto que tal "plano" não passará de mais de um instrumento destinado a levar ilusões ao sofrido homem do interior.

Estas são as razões que, entre outras, nos levaram a propor o presente projeio de Recomendação. Se êle fôr aprovado por êste Congresso, do qual com tanta sinceridade participamos, guardaremos, apenas, a convicção de que nada mais fizemos que traduzir as aspirações de nossos compatriotas do interior, sugerindo-lhes algumas diretrizes em tôrno de como devem expressá-las à Nação aqui reunida.

São Lourenço, maio de 1954 - Luciano Mesquita, Representante de Sergipe no Conselho Deliberativo da ABM.

\section{5 - OS PARECERES}

Com êste projeto de recomendação o movimento municipalista parece, afinal, passar da fase de mera doutrinação para o terreno vivo dos fatos. É por assim dizer uma antecipação do que deverá ser, de agora em diante, a orientação da Associação Brasileira de Municipios no sentido de uma politica objetiva, concreto, positiva. O seu autor, Dr. Luciano Mesquita. meminro do Conselho Deliberativo da A.B.M., submete à deliberação dêste Congresso projeto de recomendação em tôrno das medidas preliminares, politicas e administrativas, para a formulação de um Plano Nacional de Obras e Serviços Municipais (Operação Municipio) a ser executado mediante convênio entre os Municípios, os Estados e a União, contando com recursos próprios, isto é, um Fundo Nacional constituído pelas receitas provenientes dos três niveis de govêrno. O Plano, segundo as diretrizes traçadas na recomendação propostas, será elaborado de baixo para cima sob a orientação técnica de um órgão nacional de planejamento, cuja missão principal será a ce ajustar entre si as diversas partes dos planos oriundos, primàriamente, dos municípios, e, secundàriamente, dos Estados.

$\mathrm{O}$ autor assinala a necessidade de que um instrumento desta natureza seja apoiado num acôrdo interpartidário específico, de maneira a ser possível, 
por um lado, a sua elaboração e execução segundo procedimento técnico e, por outro, a minima interferência de caráter político sôbre a escolha dos projetos, os quais devem prevalecer à fôrça das necessidades econômicosecrais de cada município em particular, das regiões geo-econômicas em seguida, para afinal, se integrarem no sistema da economia nacional.

A recomendação se nos afigura da maior importância para a solução não sòmente dos problemas ligados aos municipios em si mesmos, mas para a orientação da própria economia brasileira, a qual, no dizer do Ministro Osvalilo Aranha, está requerendo um giro na direção do interior, a fim de que a sua estrutura industrial venha a apoiar-se em base sólidas.

Nessas condições, e porque estamos inteiramente de acôrdo com o projeto em aprêço, somos de parecer que o III Congresso Nacional de Municipios o aprove, mesmo porque o consideramos como ponto fundamental a qualquer programa de govêrno de nosso país.

São Lourenço, maio de 1954. - Araújo Cavalcanti, pela Assessoria Técnica, Secretário-Geral da Associação Brasileira de Municipios.

\section{$\mathrm{x} \times \mathrm{x}$}

O Estado Federal estabelece ao discriminar competência, ao lado da Uniâo soberana, a autonomia dos Estados e Municipios. Essa autonomia, svidentemente, nos países pobres como o nosso, não impede, antes estimula e exige um regime de cooperação entre os três niveis da federação. Considerando essa possibilidade de natureza constitucional, pode-se desde logo aquilatar da oportunidade da presente Recomendação, em que o autor convoca os Municípios brasileiros para um grande plano, de envergadura nacional, para o estudo e execução de obras e serviços municipais. A clareza com que é equacionado o problema, a partir da carência técnica e ausência de recursos financeiros das administrações municipais, convence-nos da necessidade inadiável de um esfôrço de conjuntura, baseado em estudos sérios e com a garantia de um "Acôrdo Interpartidário Específico". O autor mesmo declara que "Um plano de obras e serviços municipais não é emprêsa de fácil realização. E' emprêsa complexa, mas nem por isso impossível, se produto, se resultado de organizada e prudente preparação". Aprovada esta recomendação pelo Congresso - como o merece ser - acabamento e a mais precisa formulação de detalhes - os estudos ulteriores da Associação Brasileira de Municípios virão trazer em ocasião oportuna. $A^{*}$ nosso ver, êsses estudos pormenorizados hão de preservar, face aos convênios, nas soluções adotadas - a autonomia municipal. E, sem prejuízo, das tarefas de cooperação que o autor atribui à União e aos Estados, entendemos imprescindível à própria vida local, a iniciativa, para o regime de planificação, da própria aḋministração municipal.

IIm plano dessa natureza, desde que não lhe falte o lastro das pesquisas municipais, está destinado a transformar radicalmente do ponto de vista econômico e humano as comunas brasileiras, enriquecendo-as de novos fatôres de civilização. Os meios urbanos e rurais do País serão propícios a permitir o bem-estar do homem, sendo assim atingidos os verdadeiros fins da Polícia e da Administração. 
Em conclusão, nos têrmos dêste Parecer, faz jus à aprovação pelo II] Congresso dos Municípios Brasileiros, a importante Recomendação do ilustre Sr. Luciano Mesquita.

São Lourenço, maio de 1954. - Delorenzo Neto, Conselheiro da Associaçäo Brasileira de Municípios. Ex-Prefeito de Guaranézia, Sul de Minas.

Limbora a nossa palavra careça daquela expressão político-técnica de que nos fala Rui, mesmo assim não nos furtamos a registrar, embora a "voi-d'oisseau", o nosso pensamento em relação ao objetivo projeto de recomendação oferecido pelo Dr. Luciano Mesquita, dispondo normas para a organização de um Plano Nacional de Obras e Serviços Municipais.

Não há, em príncípio, assunto puramente de interêsse no Estado, de un determinado Poder Público. Tôdas as medidas discutidas ou postas em equação são como que refletidas por um televisor poderoso de proporções gigantescas, até os mais longíquos e esquecidos rincões do nosso País. Assim, como no corpo humano, hígido, existe a mais intima, perfeita e harmoniosa relação entre os seus funcional, também no âmbito nacional verifiva-se fato absolutamente semelhante.

Uma agitação provocada na opinião pública, sôbre qualquer tema, tem, muita vez, o condão de despertar o interêsse até comodistas, obrigando-os a movimentar os seus pensamentos e até os seus membros entorpecidos pelo descanso sonolento das suas poucas, mas proveitosas atividades.

Só a magnífica agitação do pensamento público, o turbilhão de argumentos mais desencontrados, entre críticas e louvores bastaria para classificar qualquer problema como remédio seguro da sua utilidade, obrigando conservadores e avançados a descobrirem suas baterias...

A hora que passa marca no invisível relógio do universo o momento próprio às grandes decisões.

O desenvolvimento dos municipios brasileiros, como peças vitais do nosso sistema federativo, constitui a base da doutrina municipalista, sôbre ser a pedra angular das fôrças vivas do País.

Para solução dos magnos problemas que assoberbam as coletividades, impöe-se a instituição de diretrizes que a muitos poderão parecer verdadeiramcrte revolucionárias, mas que nada mais exprimem do que o grau de percepção de nossas realidades, por parte daqueles que observam o desenvolvimento das causas prejudiciais ao ordenado crescimento do País e propõe normas precisas para equacioná-las.

É o caso da proposição em tela. De relevância e rara objetividade nos seus fundamentos, sôbre ser feliz e prática na solução de questões primaciais à coletividade e ao próprio ideal municipalista, porque o estudo, as pesquisas e, sobretudo, a evidência do dia a dia administrativo vão impondo a necessidade de se encontrar um sistema orgânico e propiciatório da natureza do focado.

A nosso ver, a "Operação Município", com a sua implantação, resultará passar-se da estática das palavras para a dinâmica dos fatos, mediante um planejamento racional e ajustado do desenvolvimento nacional, através dos 
órgãos hierárquicos institucionais, apoiado num acôrdo interpartidário especifico e sob regime de convênios de cooperação interadministrativa.

$\mathrm{Na}$ verdade, mais ou menos à revelia das partes beneficiadas, tem havido sempre serviços da União no Ėstado, ou de qualquer uma dessas útbitas no Municipio, envolvendo interêsses reciprocos; tem ocorrido mesmo a coexistência da mesma obra feita paralelamente pela União, Estado ou Comuna, com os prejuizos que decorrem da dispersão de recursos ou da cliversidade de orientação programáticas.

Essa pluralidade poderá ser superada através do Plano Nacional de Obras e Serviços Municipais, já que a cooperação subsidiada pode ser feita sem nenhum agravo às franquias regionais e locais e, no estágio atual da nossa educação política, é a única forma prática de se entrosarem os interêsses públicos federais, restaduais e municipais, pois não se compreende mais que serviços comuns, por ação isolada da União, do Estado ou do Município, atuem como se fôssem compartimentos estanques dentro do País.

O acôrdo triangular forçaria, assim, a solução dos problemas nacionais comuns às três órbitas, dentro do esquema prèviamente estudado, planejado e escalonado de baixo para cima, à custa do Fundo próprio, do que resultaria, poi certo, novos rumos para a vida das unidades brasileiras da nossa geografia politica.

Por tudo isso, e por muito mais que melhores e autorizadas vêzes pcderão acrescentar, é que manifestamos a nosso aplauso e o nosso apoio ao projeto, de tão alta relevância para a economia nacional, com a certeza de que, aprovado, dêle resultará de imediato, não só o florescimento da comunidade, mas, sobretudo, o alevantamento das fôrças vivas de nosso País, para maior glória do municipalismo.

São Lourenço, maio de 1954. - Vereador Manuel Ferteira de Melo Florianópolis - Santa Catarina.

d) Comissões de Planificação Municipal e da Carta de São Vicente.

Os pareceres das Comissões de Planificação Municipal e da Carta de, São Vicente foram suscintos e favoráveis às emendas, sendo que a última incluiu na Carta dos Municípios, cuja publicação se dará em breve, o item da Recomendação relativo ao Plano Nacional de Obras e Serviços Municipais.

A Comissão de Planificação Municipal, além dos debates travados entre seus membros, achou indicado ouvir os autores do projeto o que foi realizado na reunião mesma em que ela se pronunciou em favor da emenda e respectiva submenda,

\section{4 - Conclusão}

Como se verifica, propusemos à deliberação do III Congresso Nacional de Municipios a fórmula relativa a seu pronunciamento político em tôrno de como ser possivel suplementar as atividades econômico-sociais do município brasileiro. e destinada a servir de instrumento de pressão junto as autoridades públicas e aos partidos. 
Não vamos, aqui, repetir, argumentos que desenvolvemos na justificação do projeto e no artigo publicado na Revista do Serviço Público número de ma10; mas, parece-nos oportuno repisar o seguinte aspecto: se a Recomendação não vier a ser levada em consideração difícil será o caminho a percorrer peío próximo govêrno federal em matéria de assistência e cooperação financeira com os municípios.

O municipalismo está passando por uma fase extremamente perigosa. As reivindicações assumem proporções estranhas e caracteres quase absurdos.

A politização de assuntos municipais no campo federal vem sendo motivo e razão de justificados ressentimentos e ceticismo prejudicial. Observamos, no II Congresso Nacional de Municipios, uma desconfiança sistemática em relação aos propósitos e completo descrédito da capacidade dos Estados em matéria de auxílios aos municipios.

Tudo isso de mistura com a certeza de que os partidos políticos nacionais se encontram até hoje alheios ao problema das municipalidades brasileiras - antes lutando os seus associados pela supremacia politica pura e simples - mesmo que desta resultam prejuizos para o andamento de obras e serviços tidos e havidos como imprescindiveis e inadiáveis - parece ter levado o homem do interior a um estado de incompreensão maior que o justificável em relação as dificuldades reais - existentes em todos os setores da vida pública - para chegar-se a determinadas soluções. E a partir desta incom preensão adotou êsse homem do interior atitude reinvindicatória de tal proporção, e com tais matizes, que muito do procedimento de nossos homens públicos poderia ser explicado como sendo, nada mais nada menos, que tentativas desesperadas e desordenadas para amainar (embora os efeitos sejam sempre ao contrário, a irritação maior, a maior desconfiança) a assinalada atitude.

Dai a importância da organização de um plano como o proposto na recomendação. Seria êle, pelo menos, um meio seguro de orientar coisas que têm sido tentadas, mas, como... Milhares e milhares de emendas aos orç -mentos públicos. Imprevisões de tôda ordem. Descontinuidade. Desసerdicio. Centralização.

A organização do Plano teria o mérito, pelo menos, de analisar todos êsses problemas num sentido e, o que é importante, sem que êsses viessem a interferir tão frontalmente, como hoje acontece, no tratamento de problemas outros. Talvez a partir dêle fôsse possivel ordenar-se o Orçamento Federal, dar-lhe a feição técnica e a substância nacional, de natureza econômica, de que carece. Talvez a partir dêle fôsse possivel fazer-se a reforma administrativa de que necessitamos, de modo a transformar os nossos ministérios em Ministérios, isto é, em órgãos cuja missão é a de traçar política e baixar diretrizes, executando, apenas, serviços da competência da União. Talvez a partir dêle fôsse possivel atingir-se à verdadeira cooperação entre os niveis de govêrno pois a descentralização é o único processo que pode estimular relações vivas que não se pautem em papéis e burocracia. Talvez a partir dêle fôsse possivel, afinal, conseguir $\sim$ se a distinção de funções que tôda cooperação implicitamente encerra, fazendo-se dos Estados o que êles devem 
ser $€$ o são em virtude de nossa organização federativa, fazendo-se dos municipios o que êles devem ser como unidades básicas da organização nacional, fazendo-se da União o estuário das aspirações de todos e as nascentes das politicas e das diretrizes.

Enfim, é bem possível que estejamos errados. Mas, se estivermos, ainda assim parece-nos ter sido útil o levantamento da questão. Proporcionamos a nós mesmos o prazer de nos vermos contratado e contraditado e'u benefício de melhores idéias e soluções mais adequadas ao progresso do pais.

\section{O Financiamento da "Operação-Municipio"}

\section{Desiré Guarani e Silva}

Em tôda a sua profícua atividade em benefício das populações do interior do País e dos nossos Municipios, a Campanha Municipalista vem suscitando o debate dos problemas brasileiros e apresentando para os mesmos as mais indicadas soluções. $E$ estas sempre se caracterizaram pelo mais elevado sentido patriótico, conjugado com as reais possibilidades e as mais urgentes necessidades da conjuntura econômica nacional, para que se possa dàr ao brasileiro do interior do País a posição econômica e social que verdadeiramente merece dentro da comunidade nacional.

Inúmeras já foram as soluções aprovadas pelos nossos municipalistas, cida uma focalizando os aspectos de alguns dos muitos problemas nacionais Como que enfeixando tôdas elas para enfrentar o problema global de abandono do interior do País, o Congresso de São Lourenço aprovou a tese capital da Campanha Municipalista, denominada de Operação-Municipio, a qual traduz o grito de socorro que parte das abandonadas populações do interior do País. E como todo plano de caráter nacional a ser empreendido pelo Govêrno, a Operação-Municipio dequer fundos próprios, os quais devem obrigatòriamente ser encontrados nas Capitais e daí dirigidos para o interior, a fim de que possamos revitalizar a economia brasileira em suas fontes mais legítimas de riqueza benéfica a tôda a coletividade nacional.

Os mais expressivos índices econômicos e financeiros do País revelam a concentração nas grandes cidades dos resultados do trabalho do homem do interior, que lavra a terra, cultiva os campos, trabalha as minas e arranca do so!o as riquezas naturais, num esfôrço estafante e mal remunerado, para que nós, os habitantes dos grandes centros, tudo tenhamos, com menor $\epsilon$ sfôrço, em virtude da estrutura econômico-financeira do País, a qual permite qie a melhor parte do lucro que resulta das atividades do homem do campo fique concentrada nos bancos na indústria de transformação e no comércio dás grandes cidades e portos marítimos. E são justamente êsses setores da economia brasileira os que menos dão de si para o erário nacional.

A análise do sistema tributário do País revela que os setores que mais se aproveitam da economia nacional são os que menos impostos pagam. E é êsse mesmo sistema tributário que, por fenômenos típicos da taxação, permite a ilusão de que são tais setores os mais onerados pelo fisco nacional. 
Precisamos buscar, pois, justamente nesses setores, os recursos para ressuscitar o interior do Pais, dando-lhe os meios financeiros que a Operação-Municipio exige.

No impôsto do sêlo federal encontramos êsses recursos. Êles estão à disposição do erário, exigindo apenas decisão para cobrá-los. É que no campo dos empréstimos, os quais são tributados de maneira geral, operação de crédito existem yue fogem sutilmente à tributação, em virtude de uma conceituação errônea do ato econômico em que as mesmas se baseiam. Trata-se das operações de desconto, as quais, embora sejam essencialmente operações bancárias de crédito para suprimento de numerário aos clientes dos bancos e aos estabelecimentos bancários, não estão sendo abrangidas

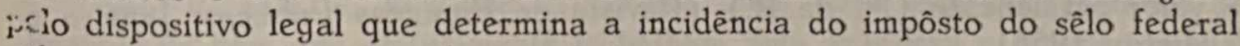
zoôbre operações idênticas de empréstimos.

Economistas e ju:istas do mais elevado quilate profissional não hesitam em conceituar como empréstimos as operações bancárias de desconto, redesconto e depósito de dinheiro. Para alcançá-las pelo gravame tributário especifico falta apenas à jurisprudência fiscal reconhecer que tais operações estão enquadradas no dispositivo que tributa os empréstimos em geral. E quando tal fôr feito, teremos ai a fonte dos recursos necessários à solução da "Operação-Município" fonte esta de recursos financeiros que é a mais indicada para êste problema, de vez que a tributação recairá sôbre as atividades bancárias que se multiplicam nos grandes centros, e que são alimentadas nas operações comerciais realizadas à custa do trabalho do homem do interior.

Teremos, com tais recursos, solucionada a "Operação-Municipio", pois as estatisticas bancárias revelam que a tributação das operações de desconto, redesconto e depósito como empréstimos fornecerão recursos anuais supesirires a três milhões de cruzeiros. E é êste o montante de recursos requerido pela "Operação-Município", a qual, desde que baseada em tal solução, não será um estímulo à imaginação de funcionários encarregados da política fiscal, mas sim um convite à capacidade realizadora dos nossos municipalistas e homens públicos devotados à solução racional dos magnos problemas que afligem as populações do interior do País.

\section{6 - o VERDADEIRO MUNICIPALISMO}

Ministro Arizio de Viana - Diretor-Geral do D.A.S.P. Administrador do Plano SALTE.

Quando da realização do II Congresso Nacional dos Municipios, levado a efeito em outubro de 1952, na cidade de S. Vicente (S.P.), um registro bastante animador foi o de que as atenções de administradores, técnicos e estudiosos das questões municipais estiveram acentuadamente voltadas para os trabalhos da mencionada convenção municipalista. Alguns dêsses elementos, de todo destaque no cenário nacional e internacional, prestigiaram aquela reunião de Prefeitos e Vereadores realizando no salão do grande plenário conferências que foram do agrado geral, pela oportunidade e 
elevação dos temas expostos. Entre tais conferencistas figurou o Sr. Minis* tro Arizio de Viana, Diretor-Geral do D.A.S.P. e Administrador do Plano SAL'TE, que levou pessoalmente seu apoio aos trabalhos de S. Vicente, através de uma conferência durante a qual disccnreu sôbre distribuição da renda pública, novos rumos da administração e municipalismo em têrmos reais. Julgamos que seria de todo interessante tranc-rever em segunda edição, para uma apreciação mais completa, a palestra realizada pelo Senhor Diretor-Geral do D.A.S.P., o que fazemos nas páginas a seguir justifica-se esıa iniciativa em face da extraordinária repercussão da Conferência do Ministro Arizio de Viana, a atualidade dos seus conceitos básicos e extrema objetividade e perenidade de seu pensamento. Trata-se de um documento de valor permanente (N. da R.) (Revista de Finanças Públicas, Janeiro e Fevereiro, 1953).

Srs, Prefeitos, Srs. Vereadores.

Constitui para mim honra excepcional dirigir-vos algumas palavras ao ensejo dêste magno Congresso em que os Municípios Brasileiros - representados pelas figuras exponenciais dos responsáveis pelos seus destinos - se reunem e se abraçam numa exemplar demonstração de cordialidade; patriotismo e senso de responsabilidade.

Brasileiros de todos os recantos acudiram ao apêlo desta tradicional e gloriosa Municipalidade de São Vicente, para um encontro de irmãos nestas paragens de beleza sem par onde, por assim dizer o Brasil deu os primeiros passos e balbuciou as primeiras palavras.

Um sentimento de profundo respeito e singular emoção domina os brasileiros - qualquer que seja a sua procedência geográfica, origens étnicas ou atuação social - ao pisarem êste sagrado pedaço da Pátria onde Martin Afonso de Souza, no princípio do Século XVI, lançou as bases das nossas instıtuições municipais.

De 1502 a 1532 viveu São Vicente e epopéia da conquista, desbravamento, posse efetiva da terra e formação da nacionalidade.

A pouco e pouco foram surgindo - com o Conselho dos homens bons, a pregação dos apóstolos e evangelisadores jesuítas, o pelourinho e os juízes do povo, meirinhos, almotacéis e colonos — os contornos da civilização brasileira.

Em meio ao tumulto do século, na luta contra corsários e flibusteiros que infestavam os mares e no esfôrço pelo dominio e assimilação dos Tamoios, fundou-se, então, em São Vicente, o $1^{\circ}$ engenho de açúcar do Brasil - fato significativo, configurando a capacidade realizadora, a energia, a tenacidade e o espírito progressista dos nossos maiores. Engenho que era, na verdade, um empreendimento de pioneiros ousados predeterminando o destino industrial de São Paulo.

Nesse periodo épico de nossa história estabeleceram-se as bases em que se apoia hoje a extraordinária expansão e desenvolvimento do Brasil.

São Vicente, ao longo das vicissitudes de sua história incomparável tem se revelado digno do glorioso passado de Piratininga. 
E um Municírio à altura dos ancestrans que o fundaram - arrojado, acolhedor e simpático - lançado na rota dos grandes destinos.

A pujar - $^{-:}$atual de São Vicente enquadra-se na sugestiva moldura de sua paisagem encantadora como prenúncio da incomensurável prosperidade que lhe reserva o futuro.

Saúdo, na pessoa do ilustre prefeito, dignos Vereadores e habitantes de. São Vicente as autoridades e populações municipais do Brasil inteiro.

\section{II - Congresso de Municipios}

São Vicente, é, portanto, o cenário ideal para esta concentração dos homens de bem que efetivamente trabalham pela grandeza e prosperidade da Nação brasileira.

Aliás, já por ocasião do 1 Congresso dos Municípios levado a efeito em abril de 1950, em Petrópolis, puderam sociólogos e estudiosos das chamadas realidades brasileiras pressentir a significação e as repercussões das iniciativas desta ordem.

A reunião dos líderes e dirigentes autênticos de 1894 Municípios, para investigação, reexame e discussão dos respectivos problemas, é acontecimento de conseqüências decisivas - tanto na órbita federal como no âmbito dos governos locais.

A periódica realização de Congressos de Municípios é, talvez de agora em diante, o acontecimento fundamental na vida politica da Federação, legítimo ato de consciência, de fé, de estimulo à ação positiva.

Senterse em cada Congresso de Municípios o próprio Brasil que se redescobre, num esfôrço para conhecer e dominar suas condições peculiares, angústias e perspectivas.

Os Municipios estabelecem ligações mais estreitas uns com os outros; efetuam proveitoso intercâmbio de idéias técnicas, ensinamentos e experiências; empreendem uma valiação mais exata de suas deficiências, recursos e potencialidades.

Osfôrço conjugado de quase 2 mil entidades do govêrno local pesquisando as anomalias estruturais e funcionais da Federação equivale a uma desapaixonada busca de soluções razoáveis ou mais convenientes para os problemas locais, regionais e nacionais.

Surgem como resultados imediatos: o conhecimento aprofundado da composição política, econômica, administrativa e social de cada Municipio; uma noção mais segura de suas necessidades e possibilidades; a fixação de novos rumos ao desenvolvimento local através da utilização adequada dos recursos humanos, materiais e institucionais da comunidade.

O I Congresso de Municípios foi uma demonstração bastante convincente das transformações que se operaram na mentalidade dos Prefeitos e Vereadores do Brasil, - todos pugnando pela descentralização geo-funcio- 
nal, pelo fortalecimento econômico financeiro, pela ampł'ação da capacidade de atuação dos respectivos Municípios mediante reivindicação de encargos paralelos aos novos recursos pleiteados.

Retoma agora êste II Congresso, com redobrado vigor, a boa orientação contida na Carta de Declaração de Princípios, Direitos e Reivindicações Municipais ou em pronunciamentos análogos inspirados nas indicações decorrentes da própria experiência de vida das comunidades.

Há uma aspiração, generalizada no sentido da formulação de planos e sistemas mais concretos de administração, bem como de um melhor entrosamento entre os órgãos governamentais que possam - sem o sacrifício das prerrogativas específicas dos Municípios - ajudá-los a executar os encargos que lhes foram conferidos.

$\mathrm{E}^{\prime}$ todo um conjunto de aplicadas relações intergovernamentais e interad́ninistrativas decorrentes da articulação de interêsses entre a União, os Estados e os Municípios, êstes últimos, todavia, aindú relegados a uma situaçăo por vêzes aflitiva em face da precariedade e insignificância de sua participação na partilha tributária.

Um dos resultados mais importantes dêsses Congressos é que Prefeitos e.Vereadores ajustam pontos de vista concretos em tôrno de um denominador comum de aspirações e procuram, ao regressar aos Municipios de origem, dar cumprimento às recomendações ou sugestões porventura aprovadas. Renovam esperanças e retemperam energias na busca de melhores niveis de bem-estar para os municipios.

Os Congressos de Municipios contribuem para identificar Prefeitos e Vereadores no exame ponderado de questões ligadas à própria sobrevivência das Comunas, e por isto mesmo revelam o meio onde se forjam verdadeiros estadistas.

Sendo o Município o agrupamento antropogeográfico fundamental onde se faz sentir com mais intensidade o impacto dos problemas quotidiahos - é, perfeitamente compreensivel serem os Prefeitos e Vereadores os nomens capazes de traduzir com objetividade, as aspirações das massas populares do País.

São êles, efetivamente, os melhores intérpretes dos interêsses nacionais.

Por êsse motivo, cumpre-nos aguardar com sincero júbilo os resultados dos estudos, discussões e entendimentos entre Congressistas oriundos de todos os pontos do nosso Território, - em sua quase totalidade, homens afeitos aos rudes trabalhos dos currais, campos e fábricas - fazendeiros, agricultores, comerciantes ou industriais que pretendem assenhorar-se do próprio destino e sugerir, nos têrmos da respectiva experiência profissional, as providências reclamadas pelas comunidades que representam.

Nenhuma oportunidade melhor para amplo, corajoso e exaustivo exame de medidas que visam as soluções em profundidade, de modo a transportar doutrinas e técnicas de desenvolvimento municipal para o plano das realizações concretas. 
Uma das principais funções dos Congressos de Municipios é contribuir para introdução em nosso Brasil das modernas práticas da administração local, tècnicamente dirigida, imune a injunções de natureza partidária.

O povo do interior, através das suas administrações locais aguarda com justificada ansiedade, assistência e orientação técnica na correção dos fatôres que agravam o desânimo e precipitam a fuga das populações rurais seduzidas pela miragem das cidades.

Os homens de responsabilidades definidas em qualquer dos niveis de govêrno encontram-se, Senhores Prefeitos e Vereadores justamente apreensivos com a fuga das populações do interior para núcleos urbanos já saturados. Afigura-se-me o despovoamento do interior um índice extremamente grave de crises latentes, e nunca se profligarão suficientemente os seus nefastos efeitos sôbre a estrutura social e econômica da Nação.

Não se deve encobrir a realidade ameaçadora com paliativos côr-de-rosa, nem ignorar a existência de um problema que é bem o diagrama de uma situaçäo anormal.

Com o desaparecimento das oportunidades de trabalho no interior do pais, sentem-se as massas orais fascinadas pela miragem de empregos mais bem remunerados nas capitais e sedes municipais.

Impõe-se deter, de qualquer maneira, silenciando o apêlo insidioso e artificial das cidades, êsse esvaziamento dos campos e estancamento das fontes de produção. Nenhum planejamento elaborado para os Municipios pode ignorar ou menosprezar a conveniência de radicação das massas rurais que constituem mais de $3 / 4$ da população brasileira.

Deve ser também examinada em todos os seus detalhes a perigosa canalização dos recursos arrecadados nas zonas rurais para aplicação por vêzes desastrosas nas capitais privilegiadas.

O revigoramento da vida local, a restauração do prestígio do Município pelo fortalecimento de suas finanças, uma criteriosa redistribuição de encargos a reorganização da administração municipal em função das tradições e realidades do meio-ambiente, constituem de fato providências dignas de cuidadoso exame. Nas condições atuais tais problemas serão resolvidos mediante conjugação dos recursos disponiveis nas 3 órbitas de Govêrno.

As medidas porventura tomadas serão todavia, materializadas no âmbito municipal.

\section{III - Diagrama de uma situação anormal}

Continuam os Municípios sofrendo as conseqüências da imperfeita distribuição das rendas públicas, a despeito das tendências favoráveis aos seus interêsses, manifestados na Contituição de 1946, e de um ligeiro desaîngo da situação financeira proporcionado pelas quotas do Impôsto de Renda que thes foram atribuidas. 
Todos êles carecem de auxilios substanciais e adequada proteção contra as mutilações de que são vítimas tanto em sua área geográfica, como no seu patrimônio demográfico e tributário.

Nunca é demais insistir sôbre o estrangulamento das iniciativas locais, em virtude dos excessos de uma centralização levada a limites incompatíveis com o desenvolvimento orgânico do Municipio.

É unânime a exigência de uma reação imediata contra absorções paralizantes, gerando a passividade, a apatia, a perigosa tendência de tudo esperar do Govêrno Central.

Velho mal cujas origens remontam ao primitivismo de uma organização agrária superada e às tradições centralizadoras das oligarquias sustentadas pelo patriarcado político.

O paradoxo é que no texto das leis estão consubstanciadas postulados de cunho eminentemente liberal, donde o Ato Adicional de 1834 à nossa tual Carta Magna, passando pela Constituição de 1891, a qual, sôbre instituir o sistema federativo, pretendeu assegurar a plenitude de autonomia municipal. Mas essa autonomia no entanto, é puramente jurídica e formal, prr isto que desprovida de conteúdo econômico e meios de ação.

Oliveira Viana acentuou com propriedade "o idealismo utópico das nossis elites", o divórcio entre a realidade nacional e os textos legais.

Tavares Bastos, Sílvio Romero, Domingos Jaguaribe, Carneiro Maia, João Barbalho e Rui Barbosa, - entre outros - já fizeram, em seus conhecidos trabalhos, o julgamento dêsse bovarismo político e propagnaram pela descentralização político-administrativa da organização nacional - instruwento capaz de levar aos mais afastados rincões do Brasil as vantagens dos serviços prestados pelos podêres públicos, a onipresença do Estado.

Descentralização que estimula e dignifica as Câmaras Municipais, restaurando-lhes o prestígio e a capacidade de ação desde os primórdios da colonização.

Não é possível, por outro lado, substituir, da noite para o dia, o panorama da vida municipal brasileira, marcado a fundo pelas absorventes e esterilizantes preocupações das qüerelas partidárias.

A pulverização das facções que se entredevoram, e personalismo. os "arranjos", abusos de autoridades policiais e privilégios de clãs enquistados, até mesmo nos mais prósperos Municípios, são dados imediatos da própria fisionomia brasileira.

Como erradicar do complexo socio-cultural da Nação "os capangas", os "cabos eleitorais", "correligionários", "compadres", demais comparsas da a.'ssa pitoresca politica de campanário, que urge, todavia, modificar?

Os textos legais são impotentes para tal empreendimentos. Impõe-se corretivos educacionais, esclarecimento da opinião popular, e, sobretudo, reorientação da política, no sentido da execução planejada de obras de longo piazo com estabelecimento de prioridades inadiáveis.

É no Município que o Povo vê e sente de perto a atuação dos órgãos integrantes da máquina governamental, contemplando, por assim dizer, a transformação dos dispositivos legais em fatos positivos. 
É no âmbito geográfico dos 1.894 Municipios e 5.427 Distritos que os integram que os serviços públicos se materializam com maior nitidez, realizando os fins do Estado tocando de perto homens, mulheres e crianças. Abastecimento dágua, rêde de esgôtos e serviços sanitários, energia elétrica, escolas, proteção de vidas e bens, alimentação, transportes, diversões - em resumo, todos os elementos indispensáveis a uma existência digna.

- Neste sentido é que se pode falar na Municipalidade como ponto de aporo e base geofísica do Estado, fundamento e unidade elementar da organizาção nacional.

Por tudo isto é que urge facultar aos Municipios os recursos de que carecem e aparelhá-los para eficiente desempenho dêsses cargos vitais. A fôrça, opulenta e prosperidade do Estado só encontram justificativa na medida em que se restaurar o prestígio do Municipio e liberar a capacidade de trabalho dos homens do Interior.

Se, como dizia Ruy Barbosa, a Pátria é a família amplificada - os Municipios são, em última análise, grupos de famílias organizadas, explorando determinados espaços geo-econômicos, usufruindo certa capacidade de autodeterminação política.

Eles são, portanto, algo mais do que um simples produto da técnica organizatória do Estado, como afirmava Pontes de Miranda.

O soerguimento dos Municipios está na razão direta da assistência dispensada aos que, na lavoura, na criação do gado, no artesanato, no comércio e nas indústrias locais, no exercício das profissões liberais e nos serviços públicos, plasmam o destino da nacionalidade e constroem a grandeza material do país.

T'ais objetivos dependem, contudo de uma ampla renovação estrutural a ser executada, simultâneamente, de baixo para cima e de cima para baixo partindo dos Municipios para atingir o Govêrno Central e. ao mesmo tempo, descendo do Govêrno Federal aos últimos povoados da República.

Aos Prefeitos e Vereadores do Brasil cabem responsabilidades definidas nessa obra de renovação nacional, sòmente possível com o saneamento da administração municipal onde se encontrem - nas Prefeituras e Câmaras locais as melhores fontes para o recrutamento de lideres e quadros dirigidos do país.

Nenhum programa do Govêrno Federal tem possibilidades de êxito nestes dias pontilhados de crises e sobressaltos, sem o apoio decisivo das administrações municipais saneadas, imunes ao perigo de improvisações, corrupção ou disputas fecciosas.

Permiti, Senhores, que vos reafirme esta minha crença irredutivel na contribuição dos Municipios à grande reforma de base que o Presidente Vargas pretende levar a efeito em beneficio do Brasil.

Justifico a minha fé no valor da participação das administrações municipais, porque, homem do interior precisamente e, modéstia a parte, como diria Rubem Braga, de Cachoeira de Itapemerim - conheço de perto a 
perenidade e singular beleza das instituições locais, a boa-fé, e tenaz operosidade dos municipios.

Perdoai-me, mas uma vez, uma ligeira referência pessoal.

Distinguido pela confiança do Presidente Getúlio Vargas, vejo-me dobrado sob a responsabilidade da Direção Geral do D.A.S.P. e Administração do Plano Salte. Encontro-me, porém, num singular pôsto de observação que me permite assistir ao funcionamento do mecanismo estatal brasileiro.

Se alguma mensagem posso transmitir-vos é a que urge descentralizar, simplificar, aperfeiçoar, eliminar instâncias interlocutórias, reduzir ou queimar etapas, transferir para os demais niveis ou órbitas da ação administrativa do Estado, grande parte das atribuições de natureza executiva.

Cumpre desenvolver a ação supletiva, orientadora e coordenadora do Govêrno Federal, estimulando, do mesmo passo, a atuação das autoridades locais - tanto mais úteis quando mais conscientes de seus deveres.

É preciso utilizar as potencialidades contidas na capacidade de iniciativas dos Governos locais, descentralizando e descongestionando, de maneira que homens e órgãos não atinjam o perigoso ponto de saturação e esgotamento de suas virtualidades.

Nos diferentes niveis de govêrno há espaço para aplicação maciça das técnicas de cooperação, acôrdos, combinações ou convênios, destinados ao ataque sinérgico aos problemas mais cruciantes das municipalidades. Exatamente alguns problemas arrolados no Temário dêste Vosso Congresso, questões de indole jurídica, econômica, social, administrativa ou puramente técnica.

O emprêgo mais intenso dos métodos e fórmulas da cooperação intergovernamental como recurso descentralizador de emergência é particularmente aconselhável na esfera administrativa.

Eis uma área de aperfeiçoamento potencial em que se fazem mister providências imediatas, quanto à organização e métodos, orçamento, adminıstração de pessoal e material, relações com o público, documentação e divu!ģação.

Os dados da experiência universal demonstram que o êxito de quaisquer reforma saneadoras da administração depende das medidas tomadas neste tempo aparentemente secundárias. Cumpre encarecer, antes de tudo, providências que objetivem a simplificação de normas e métodos de trabalho, a elevação da produtividade e do rendimento dos serviços. a definição das responsabilidades individuais, a luta contra tôdas as formas de desperdício.

Hisperar do Govêrno Federal a solução de todos os problemas é indice de sensibilidade precoce. Nem os governos regionais ou locais podem aceitar o estigma da incapacidade.

O refôrço aos processos e métodos de colaboração técnica, financeira, administrativa, em tudo quanto se refere à organização da vida rural, à intensificação dos programas de auxilios e subvenções em bases racionais, 
ao aparelhamento e funcionamento regular dos mecanismos ou instrumentalidades à vida local pode servir como ponto de partida.

A êste respeito, o Orçamento adquire novo e relevante sentido como inctrumento decisivo para correção dos desequilibrios e desniveis verificados no espaço geográfico da União.

Aplicações maciças de recursos em energia, estradas, equipamentos, fomento agropecuário e industrial, luta contra flagelos climáticos e calami dades bio-sociais, desenvolvimento de áreas retardadas, são alguns aspectos que bastam para realçar, a importância da hierarquização das despesas publicas, a decisiva participação das técnicas de Organização e do Orçamento no aproveitamento geral dos espaços econômicos, instituições ou grupos demográficos a serviço do Brasil.

\section{IV - O Verdadeiro Municipalismo}

A Carta de Declaração de Principios, Direitos e Reivindicações elaborada em abril de 1950, por ocasião do I Congresso dos Municipios em Petrópolis, contém no seu bojo permiti que vô-lo diga com franqueza de uma capixaba notórias omissões, excrescências e imperfeições. Não é êste, porém, o momento oportuno para análise das impropriedades ou méritos de um documento que foi considerado um estudo recente o "Livro de Horaes", "Breviário" da Campanha Municipalista.

Desejo, entretanto, chamar a vossa atenção para o fato de que a Carta de Petrópolis traçou as linhas definidoras de um municipalismo dinâmico, consignando algumas sugestões e indicações sumárias em que se poderá apoiar uma teoria da administração municipal adaptada as conveniências nacionais.

O Municipalismo legítimo de Tavares Bastos aos nossos dias restabelecc as tradições do prestigio moral e fôrça politica que as Câmaras Municipais gozavam nos primórdios de nossa história.

(A êste respeito, seja-me permitido observar que infelizmente Câmaras há, neste País, ainda divorciadas de padrão ideal de compostura, austeridade e espirito público de que justamente se orgulha a quase totalidade dos noss.s Vereadores).

Municipalismo legítimo é o que reagem contra a atrofia das iniciativas locais, promovendo o ressurgimento das potencialidades multifuncionais do Municipio.

E o reconhecimento da descentralização administrativa como único tipo de organização compativel com as necessidades de um País de características continentais como o Brasil.

E a luta contra o congestionamento dos centros de decisão de que só pode resultar necessàriamente uma divisão mais racional do trabalho mediante redistribuição dos encargos e responsabilidades diretivas ou executivas.

O Municipalismo verdadeiro encara a autonomia local e suas prerrogativas como imperativo de sobrevivência democrática mas estabelece, com 
objetividade, conforme acentua a Carta de Petrópolis "a conveniência de uma justa e ponderada distribuição de encargos e deveres públicos entre as 3 esferas da organização administrativa da República".

O Municipalismo verdadeiro repele a demagogia imperante; não constitui uma finalidade em si apesar da opinião em contrário de alguns patriotas delirantes; é uma atitude de espírito, uma mentalidade, um estilo de conduta poltica, um meio de obter com providências concretas a valorização. da nossa Terra e da nossa Gente.

\section{Os Novos Rumos da Administração Municipal}

Em sua quase totalidade carecem os Municípios da assistência técnica indispensável ao planejamento e execução de programas racionais de obras. ou serviços de utilidade pública.

Orçamentos reduzidos e deficiência de pessoal especializado são males crônicos que os Estados e a própria União ainda não puderam corrigir, quiçá, por motivos idênticos e pela reconhecida absolescência de um aparelhamento governamental incapaz de socorrer as administrações locais.

Por isso mesmo é que se cogita, no momento, da criação de entidades. especializadas, capazes de assegurar aos Municipios com a flexibilidade peculiar as emprêsas privadas, a assistência técnica que reclamam.

A Associação Brasileira de Municípios, já pròjetou um organismo dêsse tipo, o Instituto Brasileiro de Administração Municipal ao qual possam as Prefeituras recorrer nos casos, por exemplo, de reorganizações administrativas, administração financeira e orçamentária, implantação de reformas tributárias e do pessoal, elaboração de planos diretores para sedes municipais e distritais, serviços de água, luz, esgotos, transportes urbanos, produção, armazenagem, distribuição de mercadorias e similares, sempre que não houver possibilidade de obtenção de ajuda no âmbito dos Estados e da União.

A Assistência Técnica e baixo custo de serviços são uma constante preocupação dos nossos Prefeitos e Vereadores, como instrumento necessário a restauração do prestígio e elevação dos niveis de bem-estar das populações c localidades do interior.

Poder-se-ia, talvez afirmar que os "melhoramentos" urbanísticos concent. am grande parte das preocupações dos Municípios, monopolizado, via de regra, o interêsse de administradores nem sempre atentos aos perigos de aplicações desastradas ou dissipação dos parcos recursos disponiveis. Poucas são as cidades brasileiras que dispõem de planos diretores bem elaborados. Já se percebe, no entanto, uma tendência favorável a aceitação de agências do planejamento ou Comissões de Desenvolvimento destinadas ao preparo dos planos diretores, coordenação com outras atividades específicas das municipalidades, dentro as quais não devem ser esquecidas as de abastecimento d'água, luz, e fôrça, postos assistenciais, escolas. Nesse, como nos demais casos referentes aos interesses peculiares dos Municipios, o papel a ser desempenhado pela Câmara é sempre fundamental como um imperativo da própria democraçia Municipal. 
A prestação de serviços de assistência técnica aos Municipios vem por em evidência o pronunciamento e as aspirações do povo brasileiro no sentido de uma Reforma Administrativa tão ampla quanto profunda.

Uma reforma ligada a estruturação e funcionamento do mecanismo governamental por intermédio do qual o Estado realiza os fins que a Carta Magna lhe preestabeleceu.

Reforma técnicamente planejada e orientada no sentido de uma cautelosa e gradativa execução.

As razões de ser dessa indispensável reforma foram expostas com lucidez e admirável concisão pelo Presidente Getúlio Vargas em discurso de repercussão nacional. Permiti. Senhores Prefeitos e Vereadores, que vos exponha a sintese dêsse memorável pronunciamento do primeiro Magistrado da Nação, na parte em que consagra - êste é o têrmo - e recomencla algumas providências que de há longa data constituem aspirações generalizadas dos Municípios brasileiros.

\section{Reforma da Estrutura Administrativa do Brasil}

"Entretanto, para que nos seja possivel levar avante todos êsses empreendimentos, que são de relevante importância para o bem-estar e a fe'icidade da Nação, para conduzir tantas tarefas de grande vulto que estão a reslamar os esforços da administração, é indispensável que esta seja provida de uma estrutura condizente com a extensão e a complexidade dos problemas que reclamam a cada hora a iniciativa e a ação governamentais. Desejo hoje, com particular insistência, chamar a atenção de todos os brasileiros, e de todos os setores da opinião pública, para a necessidade de uma extensa remodelação dos instrumentos do Estado, de modo a dar-lhes maior mobilidade, flexibilidade e eficiência no interêsse do país e do serviço do povo. A estrutura administrativa de que dispomos data de uma época inteiramente diversa da realidade complexa e mutável que hoje vivemos, e não acompanhou o curso dos tempos de modo a adaptar-se às condições agora prevalecentes".

"Em todos os setores, apesar da dedicação e da operosidade da maioria dos servidores, uma anacrônica maquinaria burocrática e métodos de trabalho já zhsoletos estão a retardar e a comprometer, pela sua reduzida eficiência, - esfôrço de recuperação nacional, protelando a execução de projetos de relevante interêsse público e cerceando a cada passo a ação do Govêrno. Governar é sobretudo administrar; é através da administração que o povo sente os benéficos efeitos da atividade governamental, assim como, inversamente, as iniciativas do Govêrno podem ser frustradas pela inércia ou pelo entorpecimento de serviços públicos mal organizados ou ineficientes. A duplicação de serviços, as competições paralisantes, o desperdício dos recursos da receita pública, tudo está a impor uma reforma que consolide ai atividades e as funções de natureza similar na mesma fôrça de autoridade e na mesma unidade de objetivo. A Nação paga um ônus pesado por essa falta de ordem administrativa, e o povo já manifesta a impaciência e a 
deccrença que o assaltam ante as delongas, a morosidade e a ineficiência do aparelhamento governamental". - (Getúlio Vargas).

O Presidente Getúlio Vargas caracterizou, assim, em traços enérgicos c panorama geral da administração pública.

A reforma nos têrmos preconizados por Sua Excelência tem para os Municípios do Brasil interêsse vital como preliminar indispensável à descentralização tão ansiosamente desejada.

Qualquer que seja a reforma preconizada, a experiência de 14 anos de funcionamento do D.A.S.P., espera-se no sentido de um procedimento por etapas, procurando-se resolve um problema de cada vez sem, contudo, desligá-lo de uma inevitável articulação com os demais.

A reforma poderá ser conduzida para os objetivos estabelecidos pela lei, rendo-se em vista, principalmente, conforme recomendam os mais autorizados especialistas:

“a) estrutura dos órgãos administrativos e distribuição de competências;

b) a organização do pessoal - seleção, manutenção e aperfeiçoamento de pessoal bem qualificado;

“c) práticas administrativas - reforma dos processos gerais da atuação administrativa;

“d) modernização, simplificação;

"e) elucidação e clareza dos textos legislativos."

'Tudo isto representa para nossos Municipios interêsses vitais, constituindo. mesmo, constante preocupação de todos os cidadãos esclarecidos que há tantos anos aguardam, com a descentralização funcional, a vitória da causa municipalista.

Vamos porém concluir. Nem seria possível, nos limites de uma singela palestra esgotar temas como os que nos foi dado examinar.

Comparecendo ao II Congresso Nacional dos Municipios Brasileiros, não venho apenas transmitir os meus calorosos aplausos aos Prefeitos e Vereadores aqui reunidos. A presença do D.A.S.P. neste magnífico Congress:) de São Vicente tem outro significado profundo.

Não consiste em reafirmar, apenas o propósito de cooperar e de reiterar a declaração de que êsse órgão se acha sempre à disposição dos Governos Municipais.

Todos quantos nos têm honrado com um contato mais intimo, podem testemunhar a sinceridade da nossa atividade.

Não venho, portanto, oferecer o que todos têm o direito de exigir e reclainar.

Venho, humildemente, pedir, sinceramente convencido da fôrça indestrutivel da nossa união e dos elevados ideais que vos congregam, de aperfeiçoamento das instituições republicanas. 
Permiti, Senhores Prefeitos e Vereadores do Brasil, que vos faça, neste momento, um veemente e solene apêlo: venho solicitar o vosso encorajamento, e o vosso apoio para a obra - tanto mais necessária quanto mais dificı1 - de racionalização da administração pública brasileira.

\section{7 - OPERAÇÃo MUNIĆ́PIO}

Como no episódio bíblico, em que uma só alma justa salvaria a cidade pecaninosa, uma só resolução objetiva de um dêsses congressos que aqui, ali e açá se realizam, pode justificá-los, engrandecê-los e, sobretudo, mostrar a sua utilidade num regime verdadeiramente democrático.

E o que se verificou com o Congresso promovido pela Associação Brasileira de Municipios, ùltimamente realizado em São Lourenço. Outras não houvessem sido tomadas, uma delas, para demonstrar êsse ponto de vista. Trata-se de resolução aprovada sôbre a "Operação Municipio". Essa proposição, que sofreu acurado estudo da $3^{\text {a }}$ comissão técnica e aprovação unânime do plenário do III Congresso, recomenda a organização de um Plano Nacional de Obras e Serviços Municipais, com fundo financeiro próprio e administração especial, "aprovado em prévio acôrdo interpartidário específico", para ser executado mediante convênio, entrosando-se os grvernos municipais, estaduais e federal para o fim colimado.

Dispõe ainda essa resolução que será levada ao estudo do Congresso Nacional, ainda nesta legislatura, que, enquanto não fôr incorporada ao orçaınento da União a "operação municipio (Plano Nacional de Obras e Serviços Municipais), os prefeitos e vereadores do Brasil reivindicam um programa de Emergência, na ordem de 3 bilhões de cruzeiros, como antecip.ção de investimento total da operação, solicitando, desde já, a abertura de uin crédito especial competente".

Tal medida virá possibilitar aos municípios menos desenvolvidos, como, por exemplo. Tiradentes, em Minas; Guarapari, no Espírito Santo, e tantos vutrns, possuidores de riquezas incomensuráveis, a realizarem obras de grande alcance econômico, fora das competições partidárias e do imediatismo político. Por certo, o Congresso Nacional e o Govêrno da República compreenderão o alto alcance da sugestão, que, por si só, justificaria plenawiente o Congresso de São Lourenço.

(Jornal do Brasil - Rio de Janeiro - Domingo, 20 de junho de 1954).

\section{8 - PARECER}

Consulta do Sr. Diretor da Divisão de Orçamento do D.A.S.P. sôbre a possibilidade de serem incluídas no Orçamento da União dotações que consignem ajuda financeira aos Municipios, sem que sejam contrariados os princípios constitucionais e as normas, que condicionem a elaboração orçamentária. 
A presente consulta do Sr. Diretor da Divisão de Orçamento do Departamento Administrativo do Serviço Público, originou-se de Ofício encaminhado em 16 de janeiro de 1954, a todos os municípios brasileiros pclo Presidente do Conselho Deliberativo da Associação Brasileira dos Municípios, no sentido de se dirigirem ao Senhor Presidente da República "com um programa de investimentos e obras em condições de merecer o auxílio da União", e com a solicitação de que a verba respectiva fôsse inscrita na proposta orçamentária para 1955. Em resposta, para mais de trezentos municípios enviaram os seus expedientes à Presidência da República, correndo, em conseqüência, dúvidas em tôrno da fórmula que melhor pudesse solucionar o problema.

Passemos a examinar a questão em face do direito constitucional e das nermas de finanças públicas.

1. No texto da Constituição Federal, o Art. 73 , nos dá o princípio básicu que deve reger os desenvolvimentos do Orçamento. Assim dispõe: "o orçamento será uno, incorporando-se à receita obrigatòriamente, tôdas as rendas e suprimentos de fundos, e incluindo-se discriminadamente na despesa as dotações necessárias ao custeio de todos os serviços públicos.

"§ 18 A lei de orçamento não conterá dispositivo estranho à previsão da receita e à fixação da despesa para os serviços anteriormente criados. Não se incluem nessa proibição:

I - A autorização para abertura de créditos suplementares e operações de crédito por antecipação de receita;

II - a aplicação do saldo e o modo de cobrir o deficit.

$\S 2$ : O orçamento da despesa dividir-se-á em duas partes: uma fixa, que não poderá ser alterada senão em virtude de lei anterior; outra variável que obedecerá a rigorosa especificação".

Pois bem, o art. 73 estabelece um critério normativo em que predominam como condições necessárias à sua própria natureza a unidade, a periodicidade anual e a especialidade dos créditos. Adotado a princípio da universidade, o orçamento há de abranger tôdas as receitas e tôdas as despesas. Quanto ao custeio dos serviços públicos obedecida a exigência da discriminação, é preciso que se incluam separada e não englobadamente. Além do disposto no art. 73 , há regras especiais sôbre a aplicação anual da receita para certos casos relevantes, tais como o desenvolvimento do ensino, o Plano de defesa contra os efeitos da sêca do Nordeste e o Plano de valorização econômica da Amazônia, - consubstanciadas nos Artigos 169, 198 e 199. Evidentemente, a Seção VI, do Capítulo II da Constituição Federal, versando sôbre o Orçamento não estabelece nenhuma norma especial sôbre aplicação de dotações aos municipios, a exemplo dos artigos citados, mas também ocorre ali (como também em todo o texto constitucinnal) nenhuma cláusula negatória dessa aplicação. Por outro lado, poder-se-ia considerar como impróprio à Constituição conceder tratamento particular aos municípios ao tratar da matéria orçamentária federal, tendo em vista a discriminação rígida de rendas adotadas em correspondência a entidades intra-estatais rígidas. Nestas condições, o raciocínio nos conduziria a conceder uma economia própria para os problemas próprios, dentro 
הios orçamentos nas conformidades de sua natureza federal, estadual ou municipal. Se a discriminação de rendas estabelecida no art. 29 é de boa técnica, porque nos permite saber quais os impostos e taxas que são municipais "por natureza", e quais os impostos e taxas municipais além dêsses, isto é, "por preceitos da Constituição de cada Estado-membro", ela limita D desenvolvimento das finanças locais que assim concebida em têrmos rigidos constitui em entrave ao progresso dos municipios máxime em país como o nosso, abatido por desajustamento e crises freqüentes. Nos países que adotam o sistema flexível em matéria financeira, tôda assistência aos entes locais é facilitada através de simples mecanismo das leis ordinárias. Pcrtanto, a alegação de que os municípios desnecessitam de uma ajuda sistemática mercê do Orçamento da União, porque possuem uma economia própria fortemente alicerçada na Constituição em face da discriminação de rendas do art. 29 - não procede. Essa ajuda financeira, considerados os defeitos da discriminação constitucional, é tanto mais legitima e imprescindivel, se atentarmos à penosa situação deficitária em que se encontram as municípios brasileiros. É o de que nos convencem êsses elementos suscintos e expressivos:

Situação Geral das Finanças Municipais

- Dados do I.B.G.E

Receita global dos Municipios

- Cr\$ $1.000,00$

\begin{tabular}{l|l|l}
\hline 1948 & 1949 & 1950 \\
\hline 2.821 .655 & 3.753 .915 & 4.794 .286 \\
\hline
\end{tabular}

Deficit

\begin{tabular}{l|c|c}
\hline 1948 & 1949 & 1950 \\
\hline 77.405 & -299.787 & -401.473 \\
\hline
\end{tabular}

quadro acima denuncia a situação da crise municipal oriunda, sem duivida, em grande parte da escassês de recursos financeiros. Daí é absolutamente certa esta afirmação do Presidente do Conselho deliberativo da A.B.M., (no ofício dirigido às autoridades municipais:) "os recursos ora atribuídos aos Municipios se mostram insuficientes para a efetivação das 
obras de que os Municípios necessitam". Por isso, o espírito municipalista da Constituição precisa ser efetivado através de medidas complementares que, sem enfrentar os percalços de uma alteração do seu texto, inoportuna e demorada, possibilitaria imediato fortalecimento do poder financeiro das Prefeituras. E, dentro do espirito da Constituição - que deve ser interpretada num sentido político-social, para dar ao govêrno todos os instrumentos rossiveis que permitam a ascenção das coletividades territorialmente diferenciadas ao bem comum - é que podemos utilizar o Orçamento Federal como um meio de emergência para o atendimento de tantas reivindicações municipais.

2. Analisemos as condições técnicas em que se pode enquadrar a ajuda financeira da União aos Municipios, excluidas as hipóteses normais em que tantas vêzes ocorre através de empréstimos e subvenções. E verdade, que admitida, êle se pode tornar um meio de se tumultuar o quadro orçamentárin da União. Há de se revestir no que toca a sua utilização, de uma indeclinável seriedade de propósitos em relação aos interêsses pleiteados pelas Prefeituras, em que sobrelevem, ùnicamente, os critérios de ordem técnica e cientifica, excluidas as injunções de outra natureza. A legislação antiquada que ainda rege a elaboração orçamentária da União, não permite, é verdade, muita elasticidade na mobilização dos recursos. Contudo, enquanto se aguarda um esquema mais favorável ao equacionamento dos problemas municipais como o Código de classificação da Despesa que faz parte das Normas aprovadas pela III Conferência de Técnicos em Contabilidade Pública (in Arízio de Viana - O Orçamento Brasileito - Rio - 1950 , pág. 331), podemos, nesta emergência procurar a solução necessária nos quadros rígidos com que contamos atualmente. Neste sentido, a orientação segura assentará, certo, na utilização da Verba 3 - Serviços e Encargos, do Ministério da Justiça e Negócios Interiores. O auxílio financeiro aos Municípios poderá constar, em classificação conveniente, da Subconsignação Auxilios, da respectiva Consignação 2 - Auxílios e Subvenções. É a solução tècnicamente admissivel. Aliás, acolhida a participação direta da União. através da lei de meios, na recuperação municipal, ter-se-á adotado uma prática que concorda com a tendência moderna de ampliarem-se os quadros clássicos do orçamento. A propósito Laufenbuerger, o insigne professor de Finanças da Faculdade de Direito de Paris, declara que "Les Finances publiques ont perdu leur caractère de neutralité, elles onte ête mises partout au service de la politique economique et sociale". (Finances Coparées, Paris 1951, p. 325). Perdendo sua "neutralidade" o Orçamento da União, assistindo aos Municípios, ganhará um sentido de base. A dotação que fôr consignada, para ser atribuida a cada Prefeitura, comportará desdobramento em ordem de precedência baseada na urgência das medidas sulicitadas pelas Prefeituras Municipais, o que deverá ser feito por meio de Decreto executivo do Presidente da República. Além dessa via para o atendimento das reivindicações municipais deve ter-se em conta a utilização do Orçamento do Plano SALTE em mais de um ponto tècnicamente acessivel à atribuição de ajuda financeira em empreendimentos municipais. 
3. A escolhida do Ministério da Justiça e Negócios Interiores para exercer a assistência financeira aos Municípios, parece a mais lógica, em função das finalidades dêsse órgão da administração, destinado em parte a trałar dos problemas do interior do País. Ainda convém relembrar que sempre esteve nos intuitos do atual Govêrno ampliar os seus recursos financeiros e técnicos especializados para pô-los a serviço das justas aspirações e necessidades dos Municipios, que em sua maior parte dêles carecem para resolver seus magnos problemas de recuperação e sobrevivência. Neste sentido, era explícito o primitivo esquema de reforma administrativa elaborado pelo Govêrno Federal, que, no seu Anteprojeto estruturou o Ministério do Interior, ao qual competia entre outras atribuições a de "assistência técnica e financeira aos Municipios para execução de serviços públicos locais" ("in Arizio de Viana - DASP - Instituição a serviço do Brasil, Rio, 1953 păgina 379).

Acreditamos que a dotação do critério proposto, conciliando os princípios constitucionais e as normas vigentes de contabilidade pública, se enquadra na orientação referida, do próprio Govêrno Federal, de reconhecer a importância do Municipio como unidade básica indispensável ao progresso da Federação.

É o nosso parecer S.M.J.

São Paulo, 17 de abril de 1954. - Dr. Antônio Delorenzo Neto, Conselheiro da Associação Brasileira dos Municípios. 